\title{
In Silico Evaluation of the Potential Antiarrhythmic Effect of Epigallocatechin-3-Gallate on Cardiac Channelopathies
}

\author{
Maroua Boukhabza, ${ }^{1}$ Jaouad El Hilaly, ${ }^{1,2,3}$ Nourdine Attiya, ${ }^{2}$ Ahmed El-Haidani, ${ }^{4}$ \\ Younes Filali-Zegzouti, ${ }^{2}$ Driss Mazouzi, ${ }^{1,2}$ and Mohamed-Yassine Amarouch ${ }^{1,2}$ \\ ${ }^{1}$ Materials, Natural Substances, Environment and Modeling Laboratory, Multidisciplinary Faculty of Taza, \\ University Sidi Mohamed Ben Abdellah, Fez, Morocco \\ ${ }^{2}$ Biology, Environment \& Health Team, Department of Biology, Faculty of Sciences and Techniques Errachidia, \\ University of Moulay Ismaïl, Meknes, Morocco \\ ${ }^{3}$ Department of Life and Earth Sciences, Regional Institute of Education and Training Careers, Fez, Morocco \\ ${ }^{4}$ Team of Nutritional Physiology and Endocrine Pharmacology, Department of Biology, Faculty of Sciences and Techniques Errachidia, \\ University of Moulay Ismaïl, Meknes, Morocco
}

Correspondence should be addressed to Mohamed-Yassine Amarouch; mohamed.amarouch@usmba.ac.ma

Received 11 August 2016; Revised 21 September 2016; Accepted 29 September 2016

Academic Editor: Sharon Zlochiver

Copyright ( 2016 Maroua Boukhabza et al. This is an open access article distributed under the Creative Commons Attribution License, which permits unrestricted use, distribution, and reproduction in any medium, provided the original work is properly cited.

Ion channels are transmembrane proteins that allow the passage of ions according to the direction of their electrochemical gradients. Mutations in more than 30 genes encoding ion channels have been associated with an increasingly wide range of inherited cardiac arrhythmias. In this line, ion channels become one of the most important molecular targets for several classes of drugs, including antiarrhythmics. Nevertheless, antiarrhythmic drugs are usually accompanied by some serious side effects. Thus, developing new approaches could offer added values to prevent and treat the episodes of arrhythmia. In this sense, green tea catechins seem to be a promising alternative because of the significant effect of Epigallocatechin-3-Gallate (E3G) on the electrocardiographic wave forms of guinea pig hearts. Thus, the aim of this study was to evaluate the benefits-risks balance of E3G consumption in the setting of ion channel mutations linked with aberrant cardiac excitability phenotypes. Two gain-of-function mutations, $\mathrm{Na}_{\mathrm{v} 1.5}-\mathrm{p} . \mathrm{R} 222 \mathrm{Q}$ and $\mathrm{Na}_{\mathrm{v} 1.5}$-p.I141V, which are linked with cardiac hyperexcitability phenotypes were studied. Computer simulations of action potentials (APs) show that $30 \mu \mathrm{M}$ E3G reduces and suppresses AP abnormalities characteristics of these phenotypes. These results suggest that E3G may have a beneficial effect in the setting of cardiac sodium channelopathies displaying a hyperexcitability phenotype.

\section{Introduction}

Ion channels are transmembrane proteins that allow the passage of ions according to the direction of their electrochemical gradients across cell membranes. They are pore-forming membrane proteins whose normal function is critical for several physiological processes in cells. In excitable cells, such as cardiac cells, the activity of these proteins maintains the resting membrane potential and generates action potentials that are essential for excitation-contraction coupling process.

Ion channel dysfunction is the principal pathophysiological mechanism underlying various inherited forms of arrhythmic disorders, also called channelopathies [1]. In cardiac cells, mutations in more than 30 genes encoding ion channels have been associated with an increasingly wide range of inherited cardiac arrhythmias [1]. Examples of genetic cardiac disorders include congenital ectopic Purkinje-related premature contractions (MEPPC) and exercise induced polymorphic ventricular tachycardia (EPVT) which have been linked to the presence of the $\mathrm{Na}_{\mathrm{v} 1.5}-\mathrm{p}$.R222Q and $\mathrm{Na}_{\mathrm{v} 1.5}$-p.I141V mutations [2-4].

The ECG of the $\mathrm{Na}_{\mathrm{v} 1.5}$-p.R222Q carriers displayed atrial fibrillation, narrow junctional, and rare sinus beats competing with numerous premature ventricular contractions. The observed arrhythmia disappears under exercise [2, 3]. For $\mathrm{Na}_{\mathrm{v} 1.5}$-p.I141V carriers, the ECG is characterized by 
TABLE 1: Formulation of WT and mutated sodium channels $\left(\mathrm{Na}_{\mathrm{v} 1.5}-\mathrm{p} . \mathrm{R} 222 \mathrm{Q}\right.$ and $\left.\mathrm{Na}_{\mathrm{v} 1.5}-\mathrm{p} . \mathrm{I1} 1 \mathrm{~V} \mathrm{~V}\right)$ in the presence or absence of $30 \mu \mathrm{M}$ of E3G. The bold font corresponds to mutations effect and the bold-italic font to E3G effects.

\begin{tabular}{|c|c|c|c|c|}
\hline & TNNP/SANNBZ models, p.R222Q.I $I_{\mathrm{Na}}$ & TNNP/SANNBZ models, p.I141V.I $I_{\mathrm{Na}}$ & $\begin{array}{c}\text { TNNP/SANNBZ } \\
\text { models, } I_{\mathrm{CaL}}\end{array}$ & $\begin{array}{l}\text { TNNP/SANNB } \\
\text { models, } I_{\mathrm{Ks}} \\
\end{array}$ \\
\hline WT & $\begin{array}{c}m_{\infty}, \mathrm{WT}\left(V_{\mathrm{m}}\right)=m_{\infty}, \mathrm{WT}\left(V_{\mathrm{m}}\right) \\
\alpha_{m}, \mathrm{WT}\left(V_{\mathrm{m}}\right)=\alpha_{m}, \mathrm{WT}\left(V_{\mathrm{m}}\right) \\
\beta_{m} \mathrm{WT}\left(V_{\mathrm{m}}\right)=\beta_{m}, \mathrm{WT}\left(V_{\mathrm{m}}\right) \\
h_{\infty}, \mathrm{WT}\left(V_{\mathrm{m}}\right)=h_{\infty}, \mathrm{WT}\left(V_{\mathrm{m}}\right) \\
\beta_{h} \mathrm{WT}\left(V_{\mathrm{m}}\right)=\beta_{m}, \mathrm{WT}\left(V_{\mathrm{m}}\right)\end{array}$ & $\begin{array}{rl}m_{\infty}, \operatorname{WT}\left(V_{\mathrm{m}}\right) & =m_{\infty}, \mathrm{WT}\left(V_{\mathrm{m}}\right) \\
\alpha_{m}, \mathrm{WT}\left(V_{\mathrm{m}}\right) & =\alpha_{m}, \mathrm{WT}\left(V_{\mathrm{m}}\right) \\
\beta_{m} & \mathrm{WT}\left(V_{\mathrm{m}}\right)=\beta_{m}, \mathrm{WT}\left(V_{\mathrm{m}}\right) \\
h_{\infty}, \mathrm{WT}\left(V_{\mathrm{m}}\right) & =h_{\infty}, \mathrm{WT}\left(V_{\mathrm{m}}\right) \\
\beta_{h} \operatorname{WT}\left(V_{\mathrm{m}}\right) & =\beta_{m}, \mathrm{WT}\left(V_{\mathrm{m}}\right)\end{array}$ & $100 \%$ of $I_{\mathrm{CaL}}$ & $100 \%$ of $I_{\mathrm{Ks}}$ \\
\hline $\begin{array}{l}\mathrm{WT}+30 \mu \mathrm{M} \\
\mathrm{E} 3 \mathrm{G}\end{array}$ & $\begin{array}{c}m_{\infty}, \mathrm{WT}\left(V_{\mathrm{m}}\right)=m_{\infty}, \mathrm{WT}\left(V_{\mathrm{m}}\right) \\
\alpha_{m}, \mathrm{WT}\left(V_{\mathrm{m}}\right)=\alpha_{m}, \mathrm{WT}\left(V_{\mathrm{m}}\right) \\
\beta_{m} \mathrm{WT}\left(V_{\mathrm{m}}\right)=\beta_{m}, \mathrm{WT}\left(V_{\mathrm{m}}\right) \\
h_{\infty}, \mathrm{WT}\left(V_{\mathrm{m}}\right)=h_{\infty}, \mathrm{WT}\left(V_{\mathrm{m}}+6\right) \\
\beta_{h} \mathrm{WT}\left(V_{\mathrm{m}}\right)=\beta_{h}, \mathrm{WT}\left(V_{\mathrm{m}}\right)\end{array}$ & $\begin{array}{c}m_{\infty}, \mathrm{WT}\left(V_{\mathrm{m}}\right)=m_{\infty}, \mathrm{WT}\left(V_{\mathrm{m}}\right) \\
\alpha_{m}, \mathrm{WT}\left(V_{\mathrm{m}}\right)=\alpha_{m}, \mathrm{WT}\left(V_{\mathrm{m}}\right) \\
\beta_{m} \mathrm{WT}\left(V_{\mathrm{m}}\right)=\beta_{m}, \mathrm{WT}\left(V_{\mathrm{m}}\right) \\
h_{\infty}, \mathrm{WT}\left(V_{\mathrm{m}}\right)=h_{\infty}, \mathrm{WT}\left(V_{\mathrm{m}}+6\right) \\
\beta_{h} \mathrm{WT}\left(V_{\mathrm{m}}\right)=\beta_{h}, \mathrm{WT}\left(V_{\mathrm{m}}\right)\end{array}$ & $\mathbf{8 0} \%$ of $I_{\mathrm{CaL}}$ & $\mathbf{5 0} \%$ of $I_{\mathrm{Ks}}$ \\
\hline Mutants & $\begin{array}{c}m_{\infty}, \operatorname{p.I141V}\left(V_{\mathrm{m}}\right)=m_{\infty}, \mathrm{WT}\left(V_{\mathrm{m}}-\mathbf{6 . 3}\right) \\
\alpha_{m}, \operatorname{p.I141V}\left(V_{\mathrm{m}}\right)=\alpha_{h}, \mathrm{WT}\left(V_{\mathrm{m}}\right) \\
\beta_{m}, \operatorname{p.I141V}\left(V_{\mathrm{m}}\right)=\beta_{h}, \mathrm{WT}\left(V_{\mathrm{m}}\right) \\
h_{\infty}, \operatorname{p.I141V}\left(V_{\mathrm{m}}\right)=h_{\infty}, \mathrm{WT}\left(V_{\mathrm{m}}+\mathbf{6 . 2}\right) \\
\beta_{h} \mathrm{WT}\left(V_{\mathrm{m}}\right)=\beta_{h}, \mathrm{WT}\left(V_{\mathrm{m}}\right)\end{array}$ & $\begin{array}{c}m_{\infty}, \operatorname{p.I141V}\left(V_{\mathrm{m}}\right)=m_{\infty}, \mathrm{WT}\left(V_{\mathrm{m}}-7\right) \\
\alpha_{m}, \operatorname{p.I141V}\left(V_{\mathrm{m}}\right)=\alpha_{h}, \mathrm{WT}\left(V_{\mathrm{m}}-7\right) \\
\beta_{m}, \operatorname{p.I141V}\left(V_{\mathrm{m}}\right)=\beta_{h}, \mathrm{WT}\left(V_{\mathrm{m}}+7\right) \\
h_{\infty}, \operatorname{p.I141V}\left(V_{\mathrm{m}}\right)=h_{\infty}, \mathrm{WT}\left(V_{\mathrm{m}}\right) \\
\beta_{h} \mathrm{WT}\left(V_{\mathrm{m}}\right)=\beta_{h}, \mathrm{WT}\left(V_{\mathrm{m}}+7\right)\end{array}$ & $100 \%$ of $I_{\mathrm{CaL}}$ & $100 \%$ of $I_{\mathrm{Ks}}$ \\
\hline $\begin{array}{l}\text { Mutants }+ \\
30 \mu \mathrm{M} \mathrm{E3G}\end{array}$ & $\begin{array}{c}m_{\infty}, \operatorname{p.I141V}\left(V_{\mathrm{m}}\right)=m_{\infty}, \mathrm{WT}\left(V_{\mathrm{m}}-\mathbf{6 . 3}\right) \\
\alpha_{m}, \operatorname{p.I141V}\left(V_{\mathrm{m}}\right)=\alpha_{h}, \mathrm{WT}\left(V_{\mathrm{m}}\right) \\
\beta_{m}, \operatorname{p.I141V}\left(V_{\mathrm{m}}\right)=\beta_{h}, \mathrm{WT}\left(V_{\mathrm{m}}\right) \\
h_{\infty}, \operatorname{p.I141V~}\left(V_{\mathrm{m}}\right)=h_{\infty}, \mathrm{WT}\left(V_{\mathrm{m}}+\mathbf{6 . 2}+\mathbf{6}\right) \\
\beta_{h} \mathrm{WT}\left(V_{\mathrm{m}}\right)=\beta_{h}, \mathrm{WT}\left(V_{\mathrm{m}}\right)\end{array}$ & $\begin{array}{c}m_{\infty}, \operatorname{p.I141V}\left(V_{\mathrm{m}}\right)=m_{\infty}, \mathrm{WT}\left(V_{\mathrm{m}}-7\right) \\
\alpha_{m}, \operatorname{p.I141V}\left(V_{\mathrm{m}}\right)=\alpha_{h}, \mathrm{WT}\left(V_{\mathrm{m}}-7\right) \\
\beta_{m}, \operatorname{p.I141V}\left(V_{\mathrm{m}}\right)=\beta_{h}, \mathrm{WT}\left(V_{\mathrm{m}}+7\right) \\
h_{\infty}, \operatorname{p.I141V}\left(V_{\mathrm{m}}\right)=h_{\infty}, \mathrm{WT}\left(V_{\mathrm{m}}+6\right) \\
\beta_{h} \mathrm{WT}\left(V_{\mathrm{m}}\right)=\beta_{h}, \mathrm{WT}\left(V_{\mathrm{m}}+7\right)\end{array}$ & $80 \%$ of $I_{\mathrm{CaL}}$ & $50 \%$ of $I_{\mathrm{Ks}}$ \\
\hline
\end{tabular}

an increased sinus rate, atrial tachyarrhythmias, and an increased number of ventricular complexes during exercise [4]. On the molecular level, these mutations affect the biophysical properties of $\mathrm{Na}_{\mathrm{v} 1.5}$ by shifting its voltage dependence of steady state of activation towards more negative potentials and accelerating its activation and inactivation kinetics [2-6].

Ion channels become one of the most important molecular targets for several classes of drugs including antiarrhythmics and local anesthetic molecules [7]. In this sense, green tea flavonoids could offer a natural promising alternative. Indeed, Epigallocatechin-3-Gallate (E3G), as a major flavanol of green tea, has shown significant effects on the electrocardiographic wave forms in guinea pig. This compound has been demonstrated to exhibit inhibitory action on several cardiac ion channels [8].

Tea is manufactured from the dried leaves of Camellia sinensis in three basic forms of nonoxidized (green), semioxidized (oolong), and oxidized (black). Green tea is one of the most widely consumed beverages in North Africa and exhibits high content in polyphenolic flavanols known as catechins which may constitute up to $36 \%$ of the dry leaf weight $[9,10]$. Catechins represent $80 \%$ to $90 \%$ of green tea total flavonoids, where epigallocatechin gallate appears to be the major predominant catechin (48-55\%) followed by epigallocatechin (9-12\%), epicatechin gallate (9-12\%), epicatechin (5-7\%), and a small proportion of catechin $(0.3-$ $0.6 \%)[11]$.

Most flavonoids affect vascular system insofar to normalize blood pressure by either inhibiting calcium channels or activating potassium channels or both. But contrary to the clear-cut pathophysiological benefit of flavonoids on vascular system, the impact of these compounds on cardiac channelopathies is yet somewhat unclear [12]. Previous investigation using patch clamp technique showed that flavonoids act as multichannel inhibitors, thereby triggering generally unexpected pharmacological effects. Therefore, the reported effects on cardiac ion channels of most flavonoids remain largely unknown whether they are anti- or proarrhythmic $[12,13]$. In this sense, voltage gated sodium channel (VGSC) inhibition by polyphenols is well documented as cardioprotective and antiarrhythmic pathways. Catechins, like other polyphenols, share the common structural feature of one or more phenolic rings with several antiarrhythmic VGSC inhibitors such as lidocaine and mexiletine. These polyphenolic compounds may also inhibit peak and/or late $I_{\mathrm{Na}}$, leading to beneficial impact on the parameters associated with arrhythmias.

In this context, the aim of this study was to evaluate the benefits-risks balance of E3G effect on the setting of cardiac channelopathies.

\section{Materials and Methods}

2.1. Models. The action potentials were simulated using the updated mathematical model of the human atrial action potential of Maleckar-Greenstein-Trayanova-Giles (MGTG) [14], Stewart-Aslanidi-Noble-Noble-Boyett-Zhang (SANNBZ) Purkinje cell model [15], and Tusscher-NobleNoble-Panfilov (TNNP) human ventricular cell models [16]. 
TABLE 2: Formulation of WT and mutated sodium channels $\left(\mathrm{Na}_{\mathrm{v} 1.5}-\mathrm{p} . \mathrm{R} 222 \mathrm{Q}\right.$ and $\mathrm{Na}_{\mathrm{v} 1.5}-$ p.I141V) in the presence or absence of $30 \mu \mathrm{M}$ of $\mathrm{E} 3 \mathrm{G}$ in the Maleckar-Greenstein-Trayanova-Giles atrial cell model. The bold font corresponds to mutations effect and the bold-italic font to E3G effects.

\begin{tabular}{|c|c|c|c|c|}
\hline & MGTG atrial model, p.R222Q. $I_{\mathrm{Na}}$ & MGTG atrial model, p.I141V.I $I_{\mathrm{Na}}$ & $\begin{array}{c}\text { MGTG atrial } \\
\text { model, } I_{\mathrm{CaL}}\end{array}$ & $\begin{array}{c}\text { MGTG atrial } \\
\text { model, } I_{\mathrm{Ks}}\end{array}$ \\
\hline WT & $\begin{array}{c}m_{\infty}, \mathrm{WT}\left(V_{\mathrm{m}}\right)=m_{\infty}, \mathrm{WT}\left(V_{\mathrm{m}}\right) \\
m \text { factor, WT }\left(V_{\mathrm{m}}\right)=m \text { factor, WT }\left(V_{\mathrm{m}}\right) \\
\tau_{m}= \\
4.2 e-5(\mathrm{~s}) * \exp \left(-m_{\mathrm{factor}} * m_{\mathrm{factor}}\right)+2.4 e-5(\mathrm{~s}) \\
h_{\infty}, \mathrm{WT}\left(V_{\mathrm{m}}\right)=h_{\infty}, \mathrm{WT}\left(V_{\mathrm{m}}\right) \\
h \text { factor, WT }\left(V_{\mathrm{m}}\right)=h \text { factor, WT }\left(V_{\mathrm{m}}\right) \\
\tau_{h 1}=0.03(\mathrm{~s}) * h_{\text {factor }}+0.0003(\mathrm{~s})\end{array}$ & $\begin{array}{c}m_{\infty}, \mathrm{WT}\left(V_{\mathrm{m}}\right)=m_{\infty}, \mathrm{WT}\left(V_{\mathrm{m}}\right) \\
m \text { factor, WT }\left(V_{\mathrm{m}}\right)=m \text { factor, WT }\left(V_{\mathrm{m}}\right) \\
\tau_{m}= \\
4.2 e-5(\mathrm{~s}) * \exp \left(-m_{\text {factor }} * m_{\text {factor }}\right)+2.4 e-5(\mathrm{~s}) \\
h_{\infty}, \mathrm{WT}\left(V_{\mathrm{m}}\right)=h_{\infty}, \mathrm{WT}\left(V_{\mathrm{m}}\right) \\
h \text { factor, WT }\left(V_{\mathrm{m}}\right)=h \text { factor, WT }\left(V_{\mathrm{m}}\right) \\
\tau_{h 1}=0.03(\mathrm{~s}) * h_{\text {factor }}+0.0003(\mathrm{~s})\end{array}$ & $100 \%$ of $I_{\mathrm{CaL}}$ & $100 \%$ of $I_{\mathrm{Ks}}$ \\
\hline $\begin{array}{l}\mathrm{WT}+30 \mu \mathrm{M} \\
\mathrm{E} 3 \mathrm{G}\end{array}$ & $\begin{array}{c}m_{\infty}, \mathrm{WT}\left(V_{\mathrm{m}}\right)=m_{\infty}, \mathrm{WT}\left(V_{\mathrm{m}}\right) \\
m \text { factor, WT }\left(V_{\mathrm{m}}\right)=m \text { factor, } \\
\mathrm{WT}\left(V_{\mathrm{m}}\right) \\
\tau_{m}= \\
4.2 e-5(\mathrm{~s}) * \exp \left(-m_{\text {factor }} * m_{\mathrm{factor}}\right)+2.4 e-5(\mathrm{~s}) \\
h_{\infty}, \mathrm{WT}\left(V_{\mathrm{m}}\right)=h_{\infty}, \mathrm{WT}\left(V_{\mathrm{m}}+6\right) \\
h \text { factor, WT }\left(V_{\mathrm{m}}\right)=h \text { factor, WT }\left(V_{\mathrm{m}}\right) \\
\tau_{h 1}=0.03(\mathrm{~s}) * h_{\text {factor }}+0.0003(\mathrm{~s})\end{array}$ & $\begin{array}{c}m_{\infty}, \mathrm{WT}\left(V_{\mathrm{m}}\right)=m_{\infty}, \mathrm{WT}\left(V_{\mathrm{m}}\right) \\
m \text { factor, WT }\left(V_{\mathrm{m}}\right)=m \text { factor, WT }\left(V_{\mathrm{m}}\right) \\
\tau_{m}= \\
4.2 e-5(\mathrm{~s}) * \exp \left(-m_{\mathrm{factor}} * m_{\mathrm{factor}}\right)+2.4 e-5(\mathrm{~s}) \\
h_{\infty}, \mathrm{WT}\left(V_{\mathrm{m}}\right)=h_{\infty}, \mathrm{WT}\left(V_{\mathrm{m}}+6\right) \\
h \text { factor, WT }\left(V_{\mathrm{m}}\right)=h \text { factor, } \mathrm{WT}\left(V_{\mathrm{m}}\right) \\
\tau_{h 1}=0.03(\mathrm{~s}) * h_{\mathrm{factor}}+0.0003(\mathrm{~s})\end{array}$ & $\mathbf{8 0} \%$ of $I_{\mathrm{CaL}}$ & $50 \%$ of $I_{\mathrm{Ks}}$ \\
\hline Mutants & $\begin{array}{c}m_{\infty}, \mathrm{WT}\left(V_{\mathrm{m}}\right)=m_{\infty}, \mathrm{WT}\left(V_{\mathrm{m}}+\mathbf{6 . 3}\right) \\
m \text { factor, WT }\left(V_{\mathrm{m}}\right)=m \text { factor, WT }\left(V_{\mathrm{m}}\right) \\
\tau_{m}= \\
4.2 e-5(\mathrm{~s}) * \exp \left(-m_{\text {factor }} * m_{\mathrm{factor}}\right)+2.4 e-5(\mathrm{~s}) \\
h_{\infty}, \mathrm{WT}\left(V_{\mathrm{m}}\right)=h_{\infty}, \mathrm{WT}\left(V_{\mathrm{m}}+\mathbf{6 . 2}\right) \\
h \text { factor, WT }\left(V_{\mathrm{m}}\right)=h \text { factor, WT }\left(V_{\mathrm{m}}\right) \\
\tau_{h 1}=0.03(\mathrm{~s}) * h_{\text {factor }}+0.0003(\mathrm{~s})\end{array}$ & $\begin{array}{c}m_{\infty}, \mathrm{WT}\left(V_{\mathrm{m}}\right)=m_{\infty}, \mathrm{WT}\left(V_{\mathrm{m}}+7\right) \\
m \text { factor, WT }\left(V_{\mathrm{m}}\right)=m \text { factor, WT }\left(V_{\mathrm{m}}+7\right) \\
\tau_{m}= \\
4.2 e-5(\mathrm{~s}) * \exp \left(-m_{\text {factor }} * m_{\text {factor }}\right)+2.4 e-5(\mathrm{~s}) \\
h_{\infty}, \mathrm{WT}\left(V_{\mathrm{m}}\right)=h_{\infty}, \mathrm{WT}\left(V_{\mathrm{m}}\right) \\
h \text { factor, WT }\left(V_{\mathrm{m}}\right)=h \text { factor, WT }\left(V_{\mathrm{m}}+7\right) \\
\tau_{h 1}=0.03(\mathrm{~s}) * h_{\text {factor }}+0.0003(\mathrm{~s})\end{array}$ & $100 \%$ of $I_{\mathrm{CaL}}$ & $100 \%$ of $I_{\mathrm{Ks}}$ \\
\hline $\begin{array}{l}\text { Mutants + } \\
30 \mu \mathrm{M} \text { E3G }\end{array}$ & $\begin{array}{c}m_{\infty}, \mathrm{WT}\left(V_{\mathrm{m}}\right)=m_{\infty}, \mathrm{WT}\left(V_{\mathrm{m}}+\mathbf{6 . 3}\right) \\
m \text { factor, WT }\left(V_{\mathrm{m}}\right)=m \text { factor, WT }\left(V_{\mathrm{m}}\right) \\
\tau_{m}= \\
4.2 e-5(\mathrm{~s}) * \exp \left(-m_{\text {factor }} * m_{\mathrm{factor}}\right)+2.4 e-5(\mathrm{~s}) \\
h_{\infty}, \mathrm{WT}\left(V_{\mathrm{m}}\right)=h_{\infty}, \mathrm{WT}\left(V_{\mathrm{m}}+\mathbf{6 . 2}+\mathbf{6}\right) \\
h \text { factor, WT }\left(V_{\mathrm{m}}\right)=h \text { factor, WT }\left(V_{\mathrm{m}}\right) \\
\tau_{h 1}=0.03(\mathrm{~s}) * h_{\text {factor }}+0.0003(\mathrm{~s})\end{array}$ & $\begin{array}{c}m_{\infty}, \mathrm{WT}\left(V_{\mathrm{m}}\right)=m_{\infty}, \mathrm{WT}\left(V_{\mathrm{m}}+7\right) \\
m \text { factor, WT }\left(V_{\mathrm{m}}\right)=m \text { factor, } \mathrm{WT}\left(V_{\mathrm{m}}+7\right) \\
\tau_{m}= \\
4.2 e-5(\mathrm{~s}) * \exp \left(-m_{\text {factor }} * m_{\text {factor }}\right)+2.4 e-5(\mathrm{~s}) \\
h_{\infty}, \mathrm{WT}\left(V_{\mathrm{m}}\right)=h_{\infty}, \mathrm{WT}\left(V_{\mathrm{m}}+6\right) \\
h \text { factor, WT }\left(V_{\mathrm{m}}\right)=h \text { factor, } \mathrm{WT}\left(V_{\mathrm{m}}+7\right) \\
\tau_{h 1}=0.03(\mathrm{~s}) * h_{\text {factor }}+0.0003(\mathrm{~s})\end{array}$ & $80 \%$ of $I_{\mathrm{CaL}}$ & $50 \%$ of $I_{\mathrm{Ks}}$ \\
\hline
\end{tabular}

2.2. Formulation of Fast Sodium Current. In TNNP and SANNBZ models, the sodium current $I_{\mathrm{Na}}$ is represented according to a Hodgkin-Huxley formalism: $I_{\mathrm{Na}}=$ $g_{\mathrm{Na}} m^{3} h j\left(V_{\mathrm{m}}-E_{\mathrm{Na}}\right)$, where $g_{\mathrm{Na}}$ is the maximal conductance of $I_{\mathrm{Na}} \cdot \mathrm{m}^{3}, h$, and $j$ are the activation gate, fast inactivation gate, and slow inactivation gate, respectively. $V_{\mathrm{m}}$ represents the membrane potential, and $E_{\mathrm{Na}}$ is the Nernst potential of sodium.

For the MGTG atrial model, the sodium current $I_{\mathrm{Na}}$ is represented according to the following equation:

$$
\begin{aligned}
& I_{\mathrm{Na}} \\
& =P_{\mathrm{Na}} m^{3}\left(0.9 h_{1}+0.1 h_{2}\right)\left[\mathrm{Na}^{+}\right]_{c} V \frac{F^{2}}{\mathrm{RT}} \frac{e^{\left(V-E_{\mathrm{Na}}\right) F / \mathrm{RT}}-1}{e^{V F / \mathrm{RT}}-1},
\end{aligned}
$$

where $P_{\mathrm{Na}}$ represents the permeability to the sodium and $m^{3}, h_{1}$, and $h_{2}$ are the activation gate, fast inactivation gate, and slow inactivation gate, respectively. $V$ represents the membrane potential, and $E_{\mathrm{Na}}$ is the Nernst potential of sodium.

2.3. Computer Modeling of $N a_{v 1.5}$-p.R222Q and $N a_{v 1.5}$-p.I141V Mutants. The same strategy was used for all models of the atrial, human Purkinje cells, and left-ventricular myocytes [15-18]. As reported by Mann et al., 2012, and Swan et al., 2014, $[3,4]$, the equations corresponding to the $I_{\mathrm{Na}}$ current were modified to reproduce the relative variation of biophysical properties of the sodium current due to the $\mathrm{Na}_{\mathrm{v} 1.5}-\mathrm{p} . \mathrm{R} 222 \mathrm{Q}$ and $\mathrm{Na}_{\mathrm{v} 1.5}$-p.I141V mutations.

The effects of the $\mathrm{Na}_{\mathrm{v} 1.5}$-p.R222Q and $\mathrm{Na}_{\mathrm{v} 1.5}$-p.I141V mutations were simulated as previously described by Mann et al., 2012, and Swan et al., 2014, for the ventricular and Purkinje models $[3,4] . m_{\infty}, h_{\infty}, \alpha_{m}, \beta_{m}$, and $\beta_{h}$ were modified to reproduce the shift in the voltage dependencies of steady 


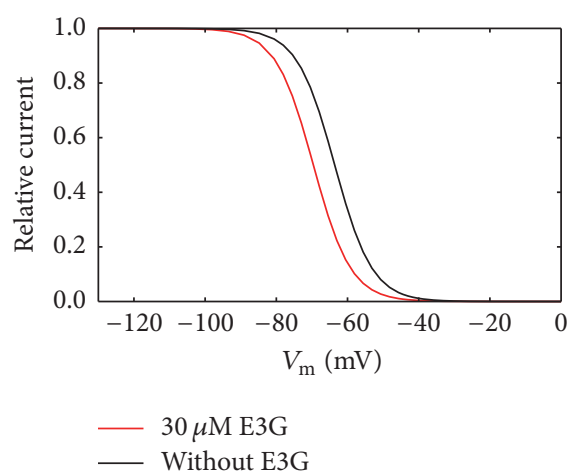

(a)

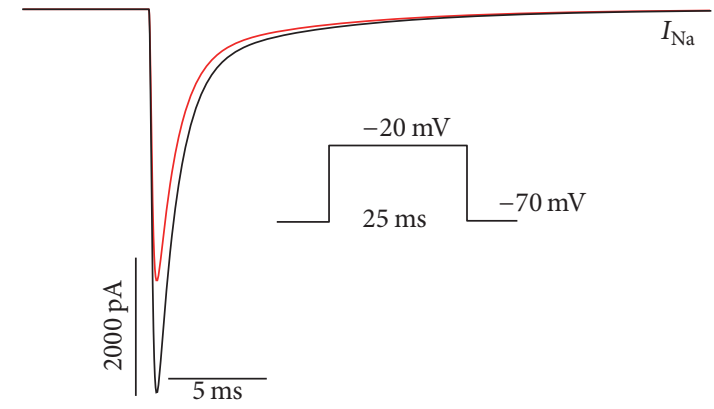

(c)

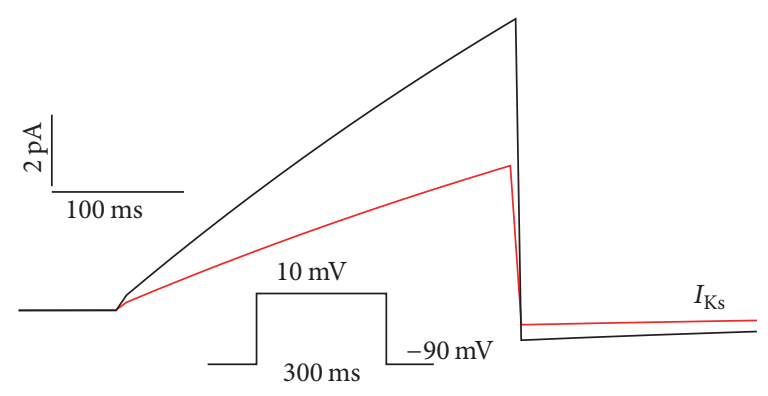

(e)

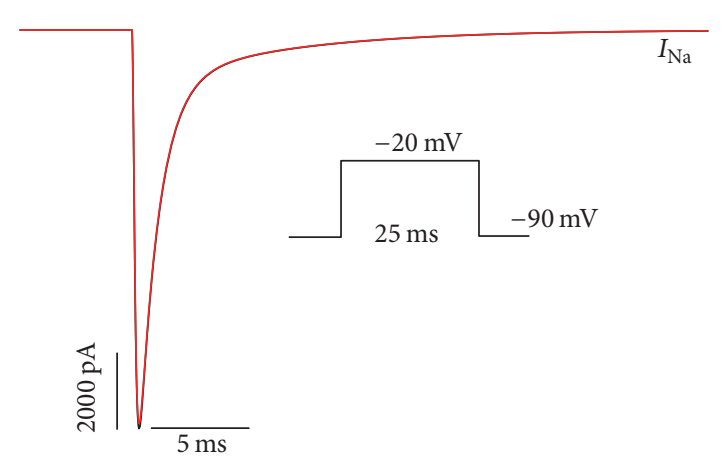

(b)

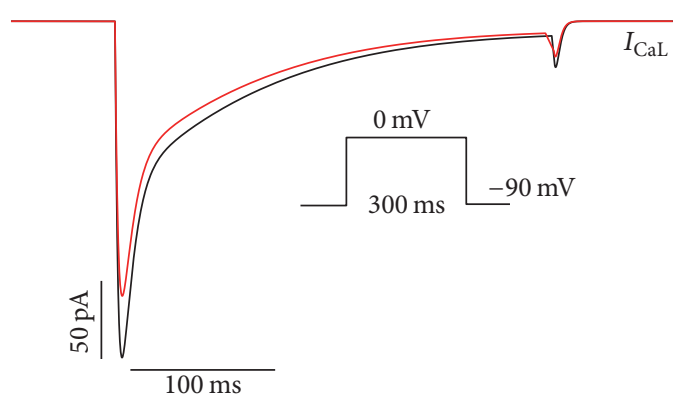

(d)

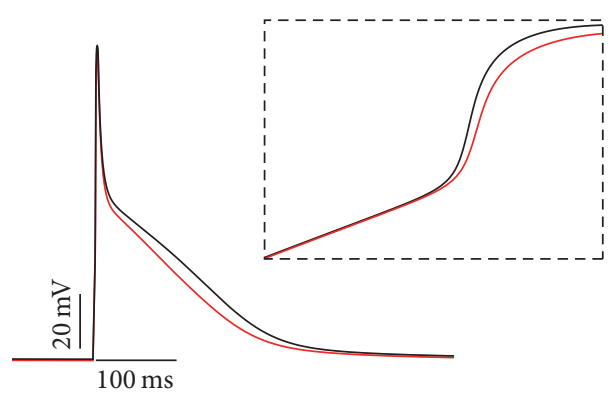

(f)

FIGURE 1: Simulated effects of $30 \mu \mathrm{M}$ E3G in the human atrial model (MGTG (Maleckar-Greenstein-Trayanova-Giles)). (a) Steady state inactivation curves $\left(h_{\infty}\right)$ in the presence or absence of E3G. (b) and (c) Inhibitory effect of E3G on the sodium current at $-90 \mathrm{mV}$ and $-70 \mathrm{mV}$ resting potentials. (d) Inhibitory effect of E3G on the calcium current (20\% inhibition). (e) Inhibitory effect of E3G on the $I_{\mathrm{Ks}}$ current (50\% inhibition). (f) E3G effect on the atrial action potential (intensity of stimulus $=15 \mu \mathrm{A} / \mu \mathrm{F}$, duration: $6 \mathrm{~ms}$; inset, zoom of the rapid depolarization phase). For all panels, black lines: without E3G; red lines: $30 \mu \mathrm{M} \mathrm{E3G.}$

state of activation and inactivation and their kinetics. For the MGTG atrial model, $m_{\infty}, m$ factor, $h_{\infty}$, and $h$ factor were modified to reproduce the shift of the activation and inactivation curves as well as the changes observed in the sodium current kinetics. In all conditions, the heterozygous states were reproduced by the summation of half the WT current and half the mutant current.

\subsection{Computer Modeling of Epigallocatechin-3-Gallate Effect} on Ion Channels. For all models and conditions (WT and mutants), the effects of $\mathrm{E} 3 \mathrm{G}$ on ion channels were reproduced based on the experimental work of Kang et al. [8].

Table 1 summarizes the modifications of the cardiac ion currents that were introduced in all models to match the experimental Data.
TABLE 3: A summary of the parameters used for the calculation of conduction velocity in the atrial, ventricular, and Purkinje models.

\begin{tabular}{lccc}
\hline Model & $\begin{array}{c}\text { Cell number } \\
(n)\end{array}$ & $\begin{array}{c}\text { Intercellular conductance } \\
(\mathrm{mS} / \mu \mathrm{F})\end{array}$ & $\begin{array}{c}\text { Step size } \\
(\mathrm{ms})\end{array}$ \\
\hline MGTG & 100 & 17 & 0.01 \\
SANNBZ & 100 & 17 & 0.01 \\
TNNP & 100 & 7 & 0.001 \\
\hline
\end{tabular}

2.5. Conduction Velocity. Conduction velocity was investigated in fibers of MGTG, TNNP, and SANNBZ cell models (pacing rates: $1 \mathrm{~Hz}$ for the atrial and ventricular models and $2.5 \mathrm{~Hz}$ for the Purkinje model). Table 3 summarizes the parameters used for the calculation of conduction velocity.

All simulations were performed by Myokit v.1.20.5 [19]. 


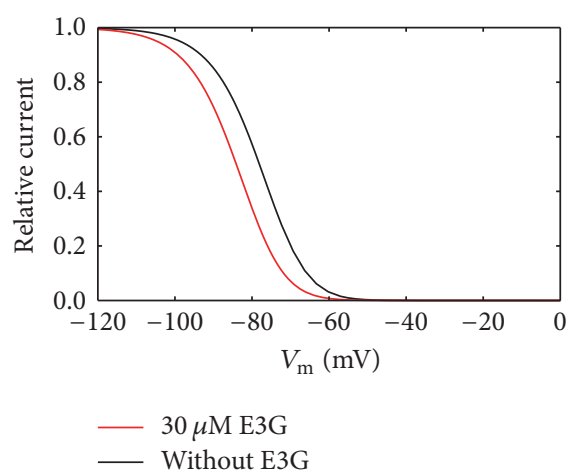

(a)

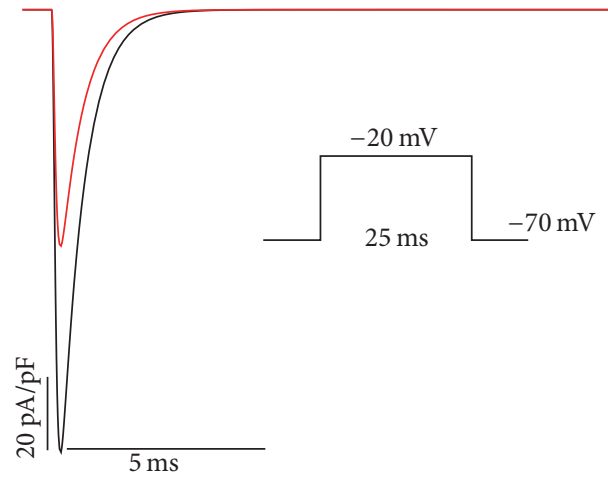

(c)

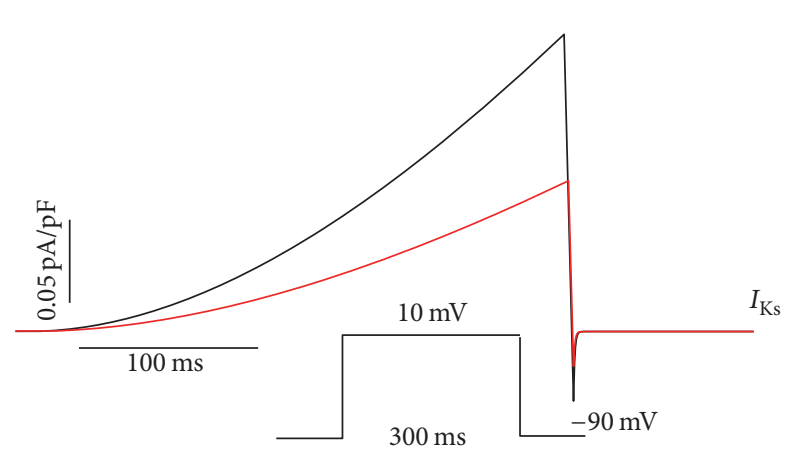

(e)

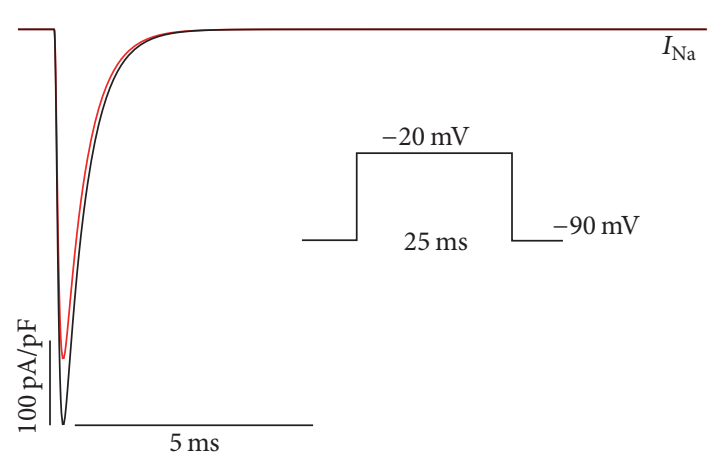

(b)

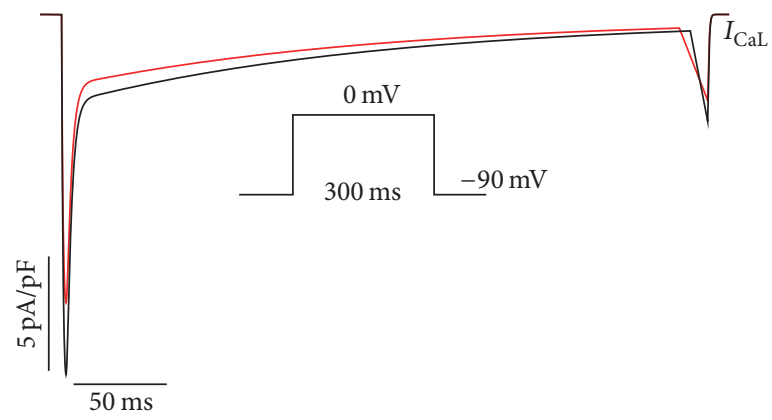

(d)

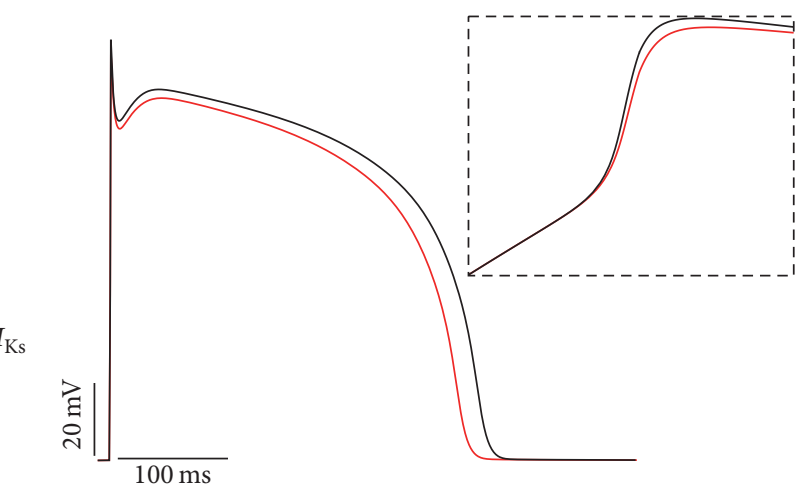

(f)

FIGURE 2: Simulated effects of $30 \mu \mathrm{M}$ E3G in the human ventricular model (TNNP [Tusscher-Noble-Noble-Panfilov]). (a) Steady state inactivation curves $\left(h_{\infty}\right)$ in the presence or absence of E3G. (b) and (c) Inhibitory effect of E3G on the sodium current at $-90 \mathrm{mV}$ and $-70 \mathrm{mV}$ resting potentials. (d) Inhibitory effect of E3G on the calcium current (20\% inhibition). (e) Inhibitory effect of E3G on the $I_{\mathrm{Ks}}$ current (50\% inhibition). (f) E3G effect on the midmyocardial action potential (intensity of stimulus $=52 \mu \mathrm{A} / \mu \mathrm{F}$, duration: $1 \mathrm{~ms}$; inset, zoom of the rapid depolarization phase). For all panels, black lines: without E3G; red lines: $30 \mu \mathrm{M}$ E3G.

\section{Results}

3.1. Simulated Effect of E3G on the Electrical Activity of Cardiac Cells. To investigate the functional consequences of $30 \mu \mathrm{M}$ E3G on the electrical activity of atrial, Purkinje, and ventricular cells, we used MGTG, SANNBZ, and human epicardial, midmyocardial, and endocardial ventricular TNNP cell models. Using these models, the observed changes in cardiac ion channels function such as voltage dependencies and current amplitudes were implemented (see Section 2, Figures 1-3).
In the $I_{\mathrm{Na}}$ formulations of MGTG, SANNBZ, and TNNP cell models, the effects of E3G on the sodium channel function were simulated by shifting the voltage dependence of the steady state equilibrium $h_{\infty}$ of $h$ gate by $-6 \mathrm{mV}$ (Figures $1(\mathrm{a}), 2(\mathrm{a})$, and $3(\mathrm{a}))$. The $m$ and $j$ gates were left unchanged.

The introduction of a negative shift in the inactivation curve, related to the presence of $\mathrm{E} 3 \mathrm{G}$, allowed us to reproduce the inhibitory effect of this compound on the sodium current amplitude for the ventricular and Purkinje cell models (Figures 2(b), 2(c), 3(b), and 3(c)). Indeed, as reported by 


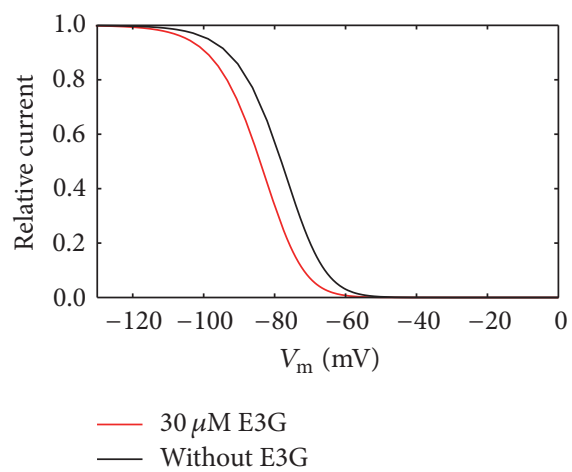

(a)

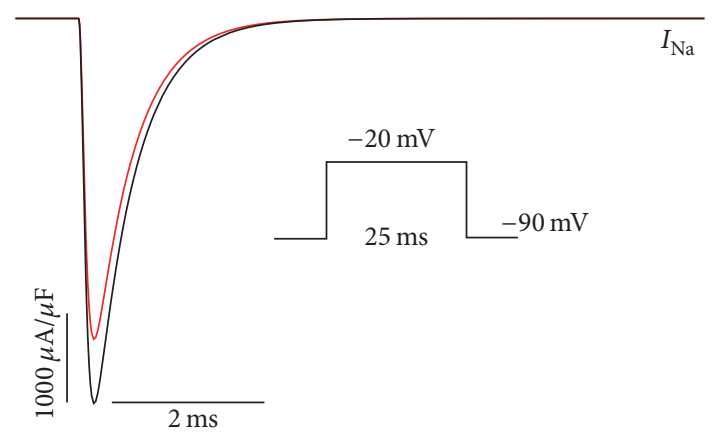

(b)

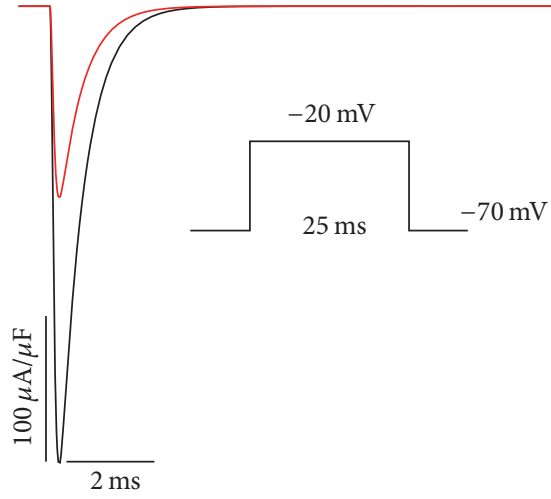

(c)

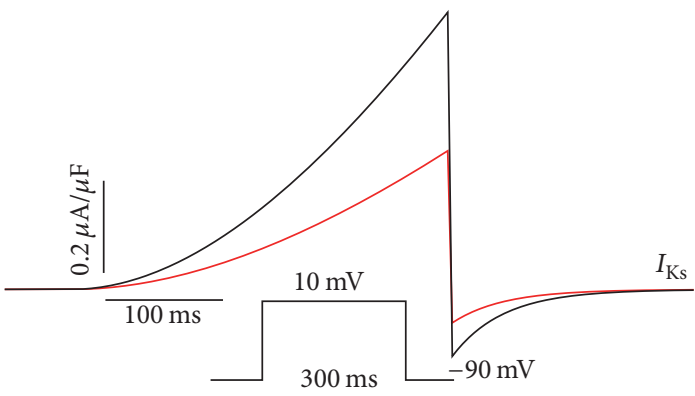

(e)

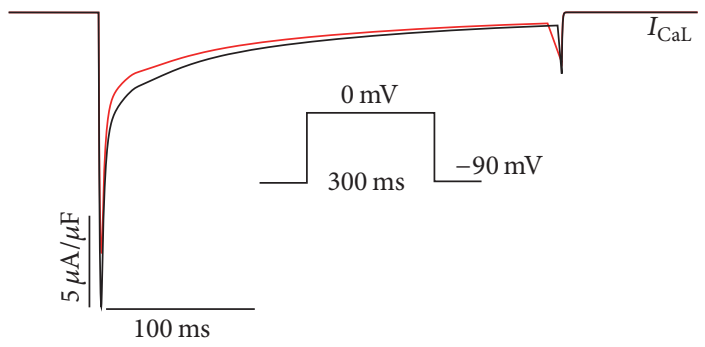

(d)

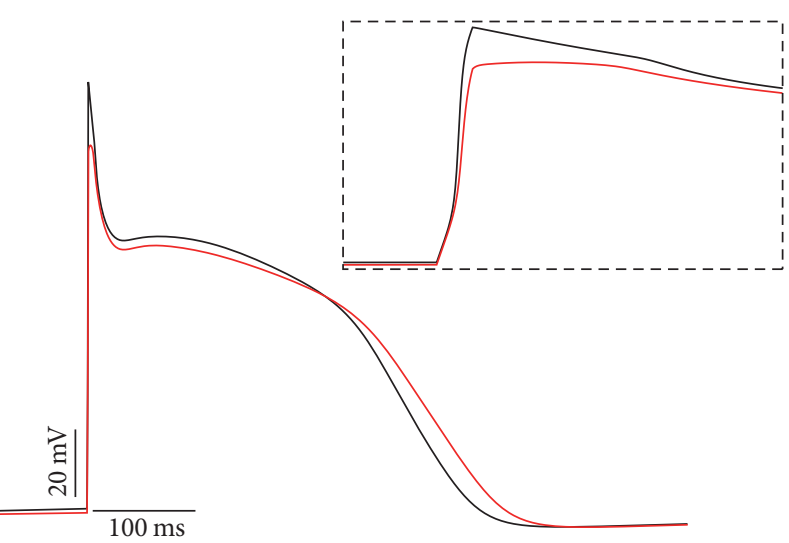

(f)

FIGURE 3: Simulated effects of $30 \mu \mathrm{M}$ E3G in the human Purkinje model (SANNBZ (Stewart-Aslanidi-Noble-Noble-Boyett-Zhang Purkinje cell model)). (a) Steady state inactivation curves $\left(h_{\infty}\right)$ in the presence or absence of E3G. (b) and (c) Inhibitory effect of E3G on the sodium current at $-90 \mathrm{mV}$ and $-70 \mathrm{mV}$ resting potentials. (d) Inhibitory effect of $\mathrm{E} 3 \mathrm{G}$ on the calcium current (20\% inhibition). (e) Inhibitory effect of E3G on the $I_{\mathrm{Ks}}$ current (25\% inhibition: dashed line; 50\% inhibition: solid line). (f) E3G effect on the Purkinje action potential (intensity of stimulus $=52 \mu \mathrm{A} / \mu \mathrm{F}$, duration: $1 \mathrm{~ms}$; inset, zoom of the rapid depolarization phase). For all panels, black lines: without E3G; red lines: $30 \mu \mathrm{M}$ E3G.

Kang et al. [8], the inhibitory effect of E3G is higher at depolarized resting potentials. However, for the atrial cell model, we observed that $30 \mu \mathrm{M}$ E3G decreases the sodium current amplitude only when the resting potential is maintained at $-70 \mathrm{mV}$ (Figures $1(\mathrm{~b})$ and $1(\mathrm{c})$ ). There is no E3G effect when the resting potential is maintained at $-90 \mathrm{mV}$. This is due to the biophysical properties of inactivation at basal condition. In fact, as shown in Figure 1(a), there is no difference in the sodium channel availability with or without E3G at $-90 \mathrm{mV}$. Thus, an equal number of sodium channels were available in both conditions when the membrane was maintained at this potential.

Moreover, by using the same voltage protocols described by Kang et al., the inhibitory effect of $30 \mu \mathrm{M}$ E3G on $I_{\mathrm{CaL}}$ and $I_{\mathrm{Ks}}$ currents was reproduced via decreasing the amplitude of these currents to $80 \%$ and $50 \%$ of WT amplitude, respectively 


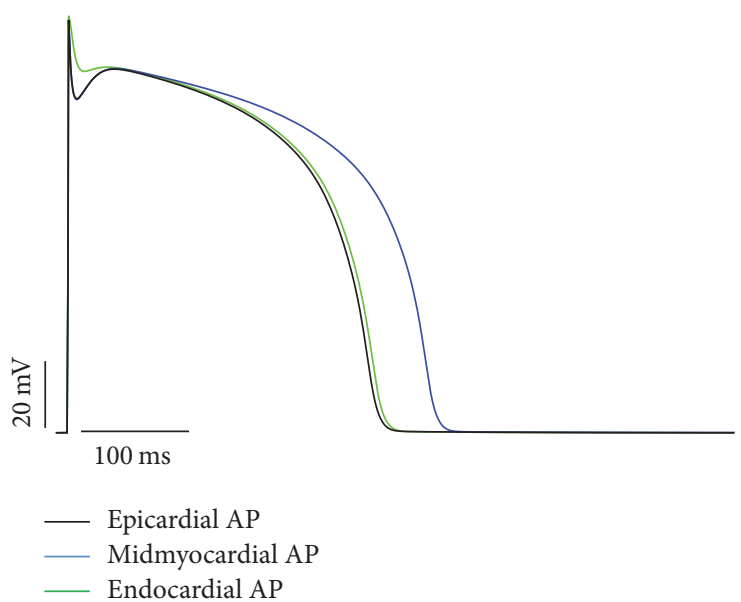

(a) Epi-, midmyo-, and endocardial cell models

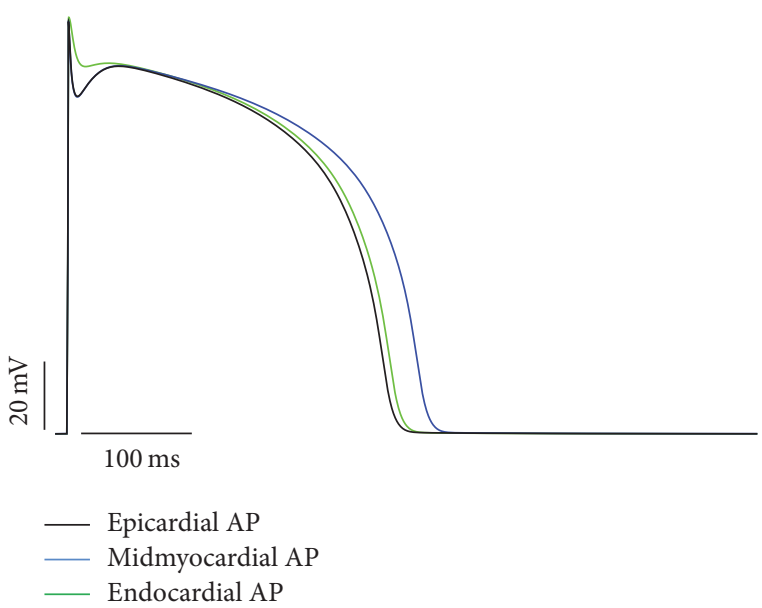

(b) Epi-, midmyo-, endocardial cell models

FIGURE 4: Repolarization dispersion across the ventricular wall. (a) Superimposition of the epi-, midmyo-, and endocardial action potentials (TNNP cells models) in absence of E3G. (b) Superimposition of the epi-, midmyo-, and endocardial action potentials in the presence of $30 \mu \mathrm{M}$ E3G.

TABLE 4: The effect of E3G on conduction velocity investigations in the presence of p.R222Q and p.I141V in heterozygous states.

\begin{tabular}{|c|c|c|c|c|c|c|}
\hline \multirow{2}{*}{$\begin{array}{l}\text { Model } \\
\text { Condition }\end{array}$} & \multicolumn{2}{|c|}{ Atrial cells } & \multicolumn{2}{|c|}{ Ventricular cells } & \multicolumn{2}{|c|}{ Purkinje cells } \\
\hline & $\begin{array}{c}\mathrm{CV}(\mathrm{cm} / \mathrm{s}) \\
\text { control }\end{array}$ & $\begin{array}{c}\mathrm{CV}(\mathrm{cm} / \mathrm{s}) \\
30 \mu \mathrm{M} \mathrm{E} 3 \mathrm{G}\end{array}$ & $\begin{array}{c}\mathrm{CV}(\mathrm{cm} / \mathrm{s}) \\
\text { control }\end{array}$ & $\begin{array}{l}\mathrm{CV}(\mathrm{cm} / \mathrm{s}) \\
30 \mu \mathrm{M} \mathrm{E} 3 \mathrm{G}\end{array}$ & $\begin{array}{c}\mathrm{CV}(\mathrm{cm} / \mathrm{s}) \\
\text { control }\end{array}$ & $\begin{array}{l}\mathrm{CV}(\mathrm{cm} / \mathrm{s}) \\
30 \mu \mathrm{M} \mathrm{E} 3 \mathrm{G}\end{array}$ \\
\hline $\mathrm{Na}_{\mathrm{v} 1.5} \mathrm{WT}$ & 55.07 & 50.84 & 49.91 & 45.72 & 67.68 & 37.20 \\
\hline $\mathrm{Na}_{\mathrm{v} 1.5}$ p.I141V & 57.44 & 53.93 & 53.63 & 49.11 & 72.43 & 42.92 \\
\hline $\mathrm{Na}_{\mathrm{v} 1.5}$ p.R222Q & 60.93 & 56.23 & 51.93 & 45.56 & 62.72 & - \\
\hline
\end{tabular}

(Figures 1(d), 1(e), 2(d), 2(e), 3(d), and 3(e)). All used formulations are summarized in Tables 1 and 2 (see Section 2). Simulations were run for $60 \mathrm{~s}$ with a cycle length of $1 \mathrm{~Hz}$ to stabilize the model. Then, supplementary run was started for another $5 \mathrm{~s}$ and then the last AP of each supplementary run was analyzed.

The combined effects of $30 \mu \mathrm{M}$ E3G on cardiac ion channels slightly decreased the AP amplitudes and maximum upstroke velocities of atrial, Purkinje, and ventricular cells (Figures 1(f), 2(f), and 3(f)). In addition, the plateau phase of atrial AP was reduced (Figure 1(f)). However, E3G increased AP duration in Purkinje cell model (Figure 2(f)).

For midmyocardial cells, E3G shortened the AP duration (Figure 3(f)). On the other hand, the superimposition of the epi-, midmyo-, and endocardial APs predicted a small decrease of the repolarization dispersion across the ventricular wall (Figure 4).

\subsection{The p.R222Q and p.I141V Effects on Cardiac Excitability.} According to the experimental work of Kang et al. [8], the E3G antiarrhythmic effect, in the sitting of MEPPC and EPVT cardiac disorders, was evaluated. First, we incorporated the biophysical modifications that are induced by the $\mathrm{Na}_{\mathrm{v1} 15^{-}}$ p.R222Q and $\mathrm{Na}_{\mathrm{v} 1.5}$-p.I141V mutations and got insight on their effects on atrial, ventricular, and Purkinje APs using MGTG, TNNP, and SANNBZ models (Figures 5, 6, and 7).

Interestingly, the introduction of equations mimicking the heterozygous state into the atrial and ventricular cell models induced minor changes in their AP morphologies (Figures 8(a), 8(b), 9(a), 9(b), 10(a), 10(b), 11(a), and 11(b)). Conversely, Mann et al. and Swan et al. [3, 4] reported a drastic effect when these equations are introduced in the Purkinje cell model. Indeed, for the $\mathrm{Na}_{\mathrm{v} 1.5}-\mathrm{p} . \mathrm{R} 222 \mathrm{Q}$ and $\mathrm{Na}_{\mathrm{v} 1.5}$-p.I141V mutants, the model showed an accelerated rate of spontaneous activity of Purkinje cells leading to the occurrence of ectopic beats during the diastolic interval at $1 \mathrm{~Hz}$ (Figures 12(a), 12(b), 13(a), and 13(b)). These abnormalities disappeared at higher pacing rates (Data not shown).

On the other hand, using MGTG, TNNP, and SANNBZ models, strength-duration curves were constructed. In the presence of $\mathrm{Na}_{\mathrm{v} 1.5}$-p.R222Q and $\mathrm{Na}_{\mathrm{v} 1.5}$-p.I141V mutations, a lower excitation threshold for action potential generation (pacing rates: $1 \mathrm{~Hz}$ for atrial and ventricular models and $2.5 \mathrm{~Hz}$ for the Purkinje model) was observed in the p.R222Q and p.I141V mutations in homozygous and heterozygous genotypes compared with the WT ((d) in Figures 8-13).

Conduction velocity was investigated in fibers of MGTG, TNNP, and SANNBZ cell models (pacing rates, as described above). The presence of the $\mathrm{Na}_{\mathrm{v} 1.5}$-p.I141V mutation, in homozygous and heterozygous states, accelerated atrial and ventricular conduction at $1 \mathrm{~Hz}$ and Purkinje conduction at $2.5 \mathrm{~Hz}$. Similar variations were observed in $\mathrm{Na}_{\mathrm{v} 1.5}-\mathrm{p} . \mathrm{R} 222 \mathrm{Q}$ mutation, whereas the conduction velocity was lower than WT condition in Purkinje cell model at $2.5 \mathrm{~Hz}$ pacing rate (Table 4). 

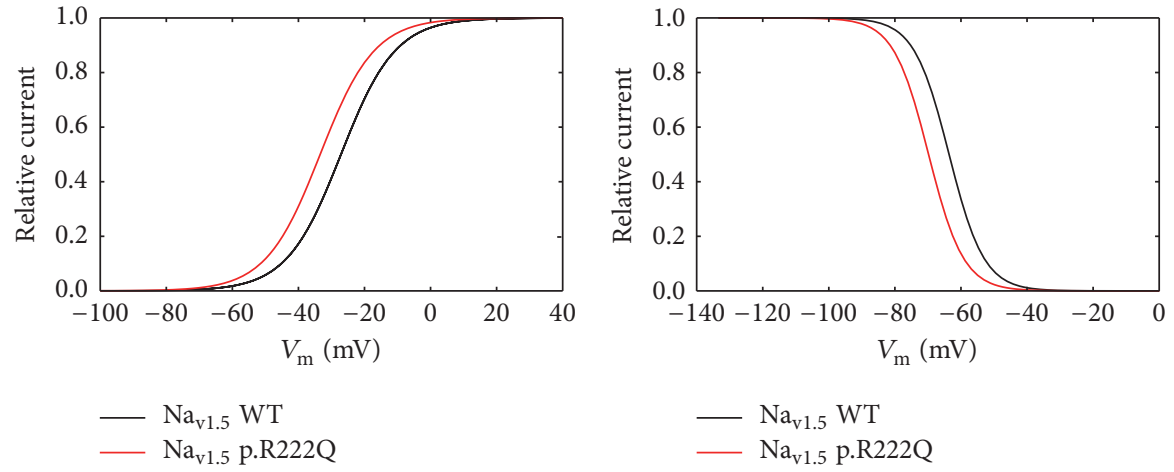

(a)

(b)
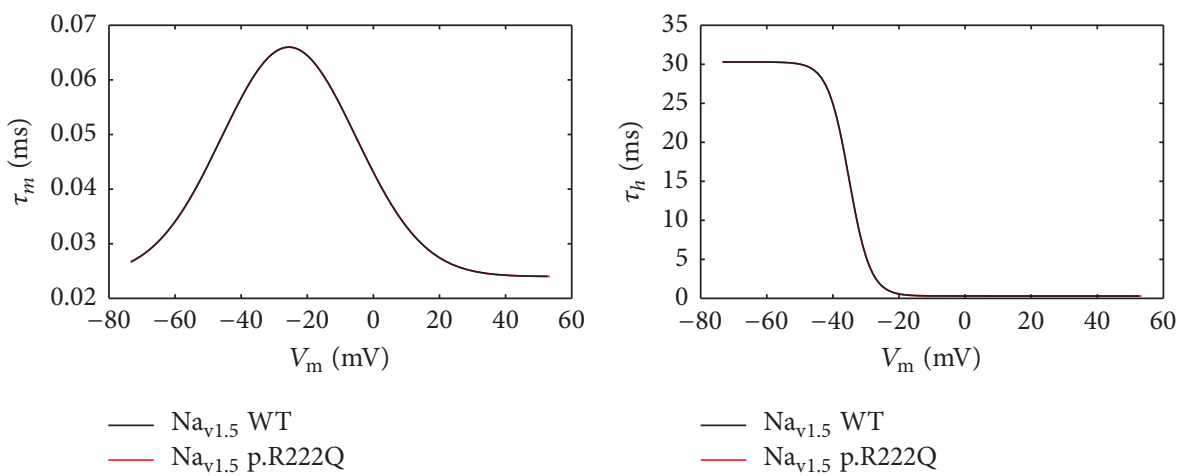

(c)

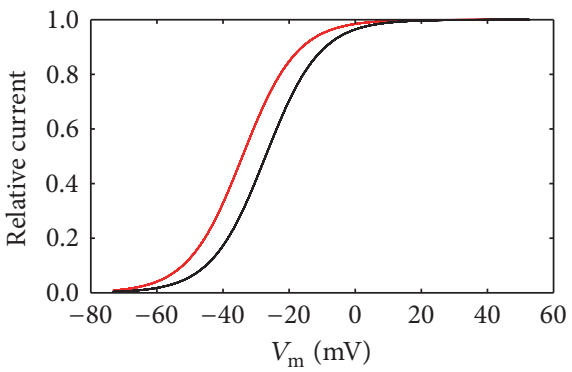

(d)

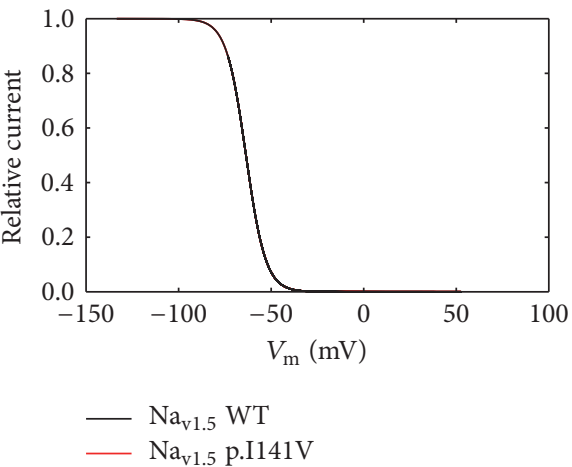

(f)
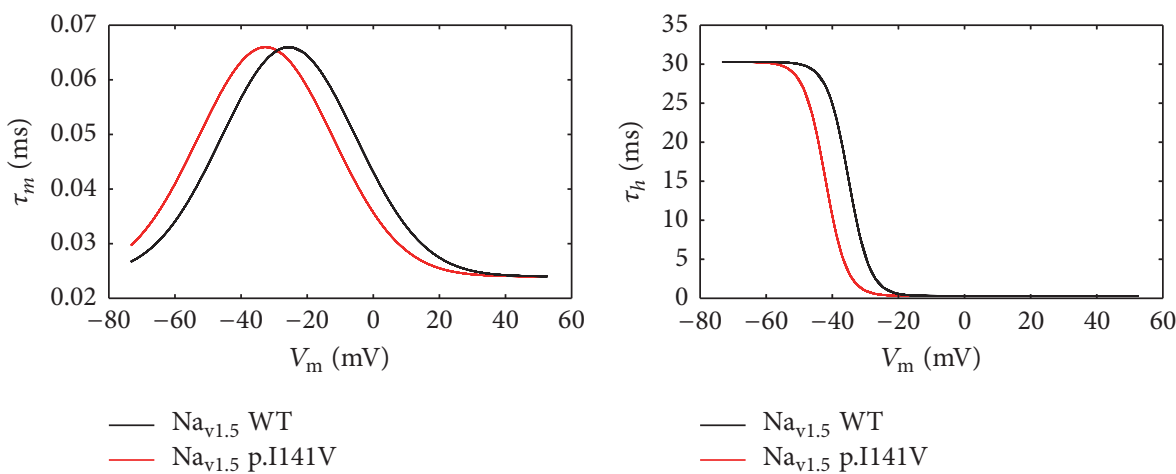

(h)

FIGURE 5: Effects of the p.R222Q and p.I141V mutations on $I_{\mathrm{Na}}$ properties in the human atrial cell model (MGTG cell model). (a) and (b) Effect of the p.R222Q mutation on the voltage dependence of steady state of activation and inactivation. (c) and (d) Effect of the p.R222Q mutation on the activation and inactivation kinetics. (e) and (f) Effect of the p.I141V mutation on the voltage dependence of steady state of activation and inactivation. $(\mathrm{g})$ and $(\mathrm{h})$ Effect of the p.I141V mutation on the activation and inactivation kinetics. For all panels, black lines: WT condition; red lines: mutant conditions. 

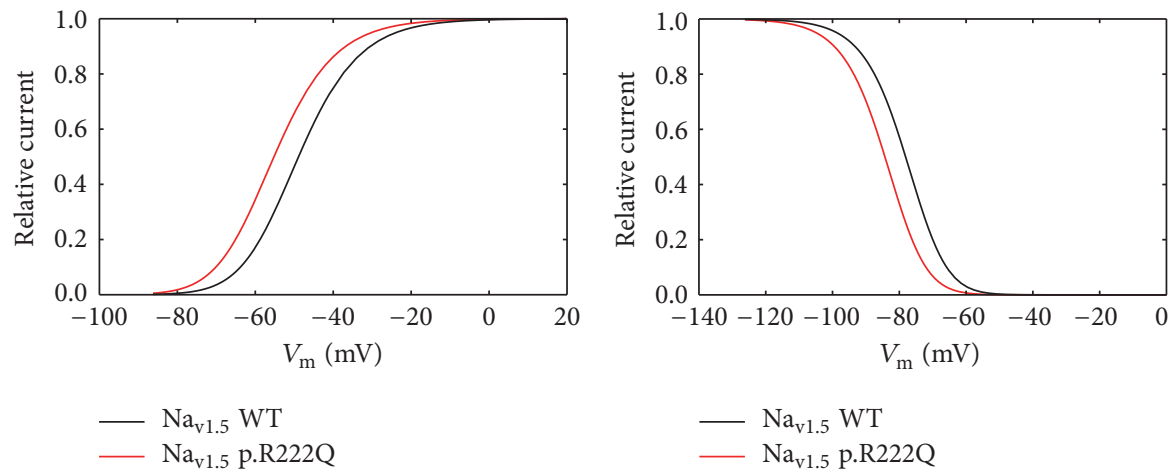

(a)

(b)
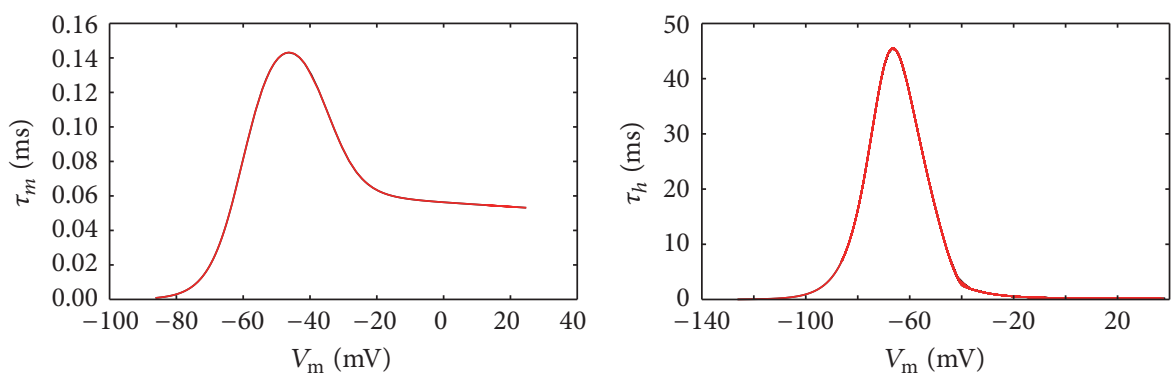

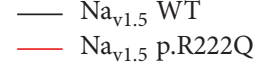

(c)

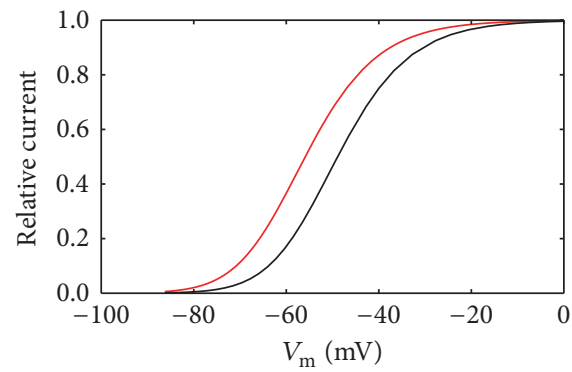

$-\mathrm{Na}_{\mathrm{v} 1.5} \mathrm{WT}$

$-\mathrm{Na}_{\mathrm{v} 1.5}$ p.I141V

(e)

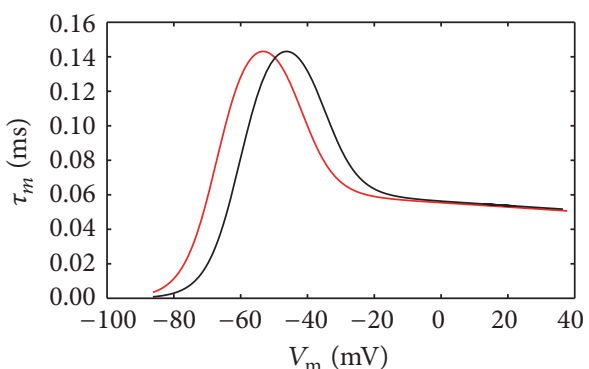

- $\mathrm{Na}_{\mathrm{v} 1.5}$ WT

$-\mathrm{Na}_{\mathrm{v} 1.5}$ p.I141V

(g)
- $\mathrm{Na}_{\mathrm{v} 1.5} \mathrm{WT}$

$-\mathrm{Na}_{\mathrm{v} 1.5}$ p.R222Q

(d)

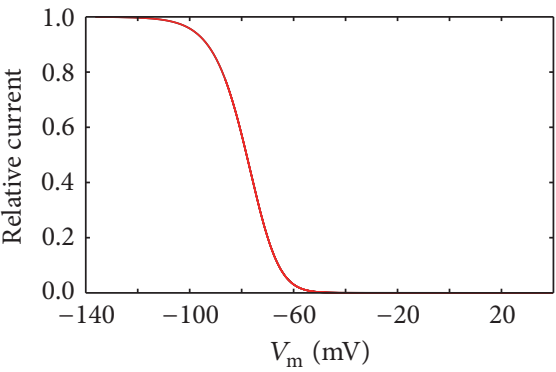

$-\mathrm{Na}_{\mathrm{v} 1.5} \mathrm{WT}$

$-\mathrm{Na}_{\mathrm{v1}} .5$ p.I141V

(f)

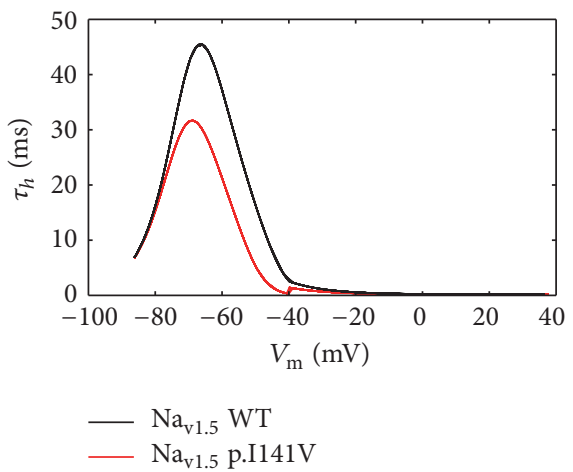

(h)

FIGURE 6: Effects of the p.R222Q and p.I141V mutations on $I_{\mathrm{Na}}$ properties in the human ventricular cell model (TNNP cell model). (a) and (b) Effect of the p.R222Q mutation on the voltage dependence of steady state of activation and inactivation. (c) and (d) Effect of the p.R222Q mutation on the activation and inactivation kinetics. (e) and (f) Effect of the p.I141V mutation on the voltage dependence of steady state of activation and inactivation. $(\mathrm{g})$ and $(\mathrm{h})$ Effect of the p.I141V mutation on the activation and inactivation kinetics. For all panels, black lines: WT condition; red lines: mutant conditions. 


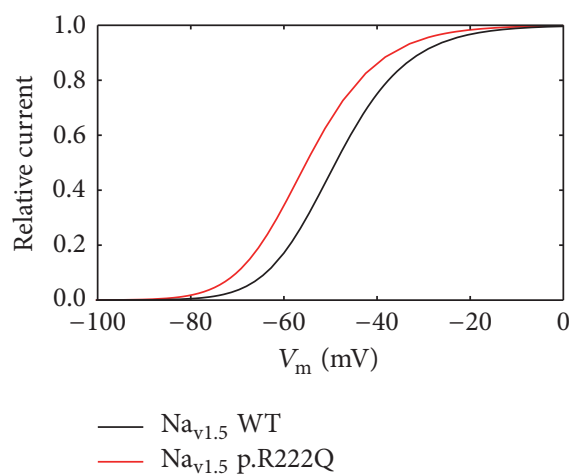

(a)

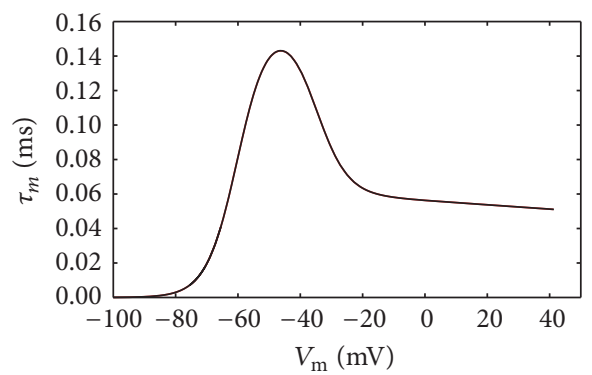

$-\mathrm{Na}_{\mathrm{v} 1.5} \mathrm{WT}$
$\mathrm{Na}_{\mathrm{v} 1.5}$ p.R222Q

(c)

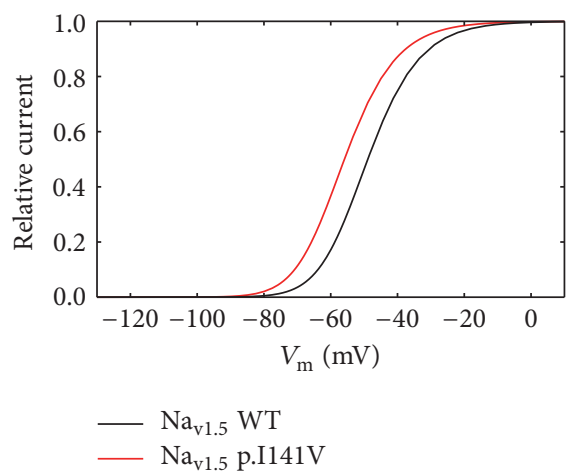

(e)

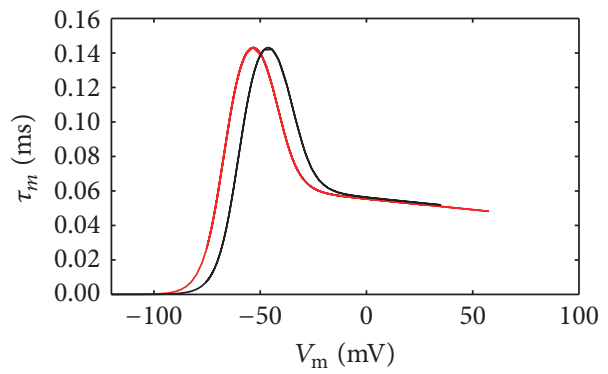

$-\mathrm{Na}_{\mathrm{v} 1.5} \mathrm{WT}$
$\mathrm{Na}_{\mathrm{v} 1.5}$ p.I141V

(g)

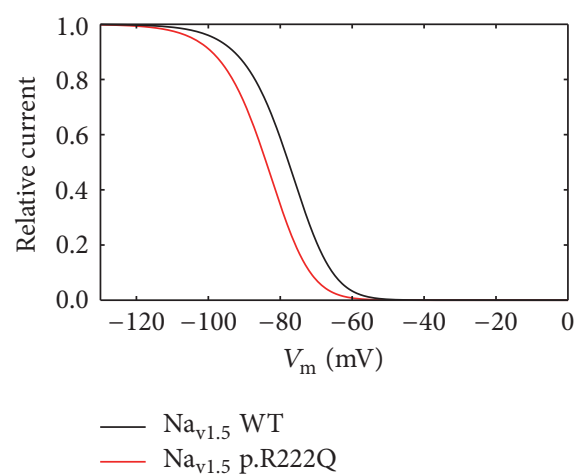

(b)

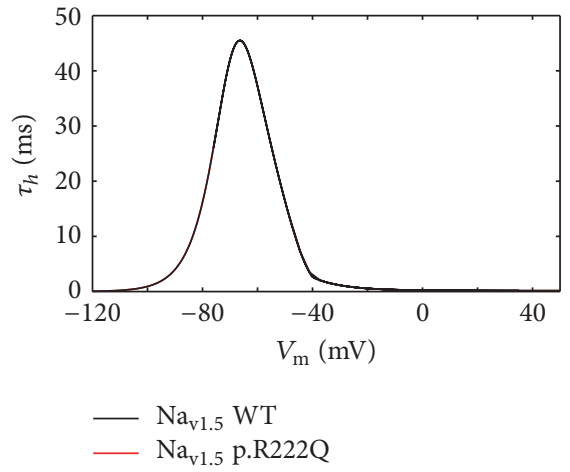

(d)

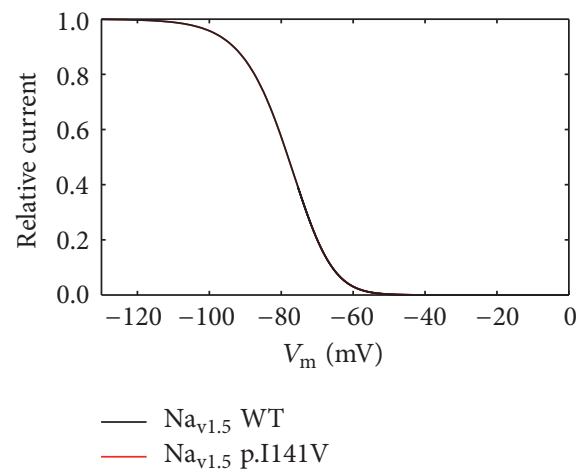

(f)

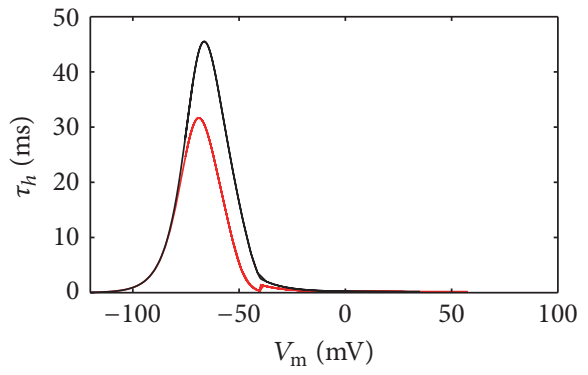

$\mathrm{Na}_{\mathrm{v} 1.5} \mathrm{WT}$
$\mathrm{Na}_{\mathrm{v} 1.5}$ p.I141V

(h)

FIGURE 7: Effects of p.R222Q and p.I141V mutations on $I_{\text {Na }}$ properties in the human Purkinje cell model (SANNBZ cell model). (a) and (b) Effect of the p.R222Q mutation on the voltage dependence of steady state of activation and inactivation. (c) and (d) Effect of the p.R222Q mutation on the activation and inactivation kinetics. (e) and (f) Effect of the p.I141V mutation on the voltage dependence of steady state of activation and inactivation. (g) and (h) Effect of the p.I141V mutation on the activation and inactivation kinetics. For all panels, black lines: WT condition; red lines: mutant conditions. 


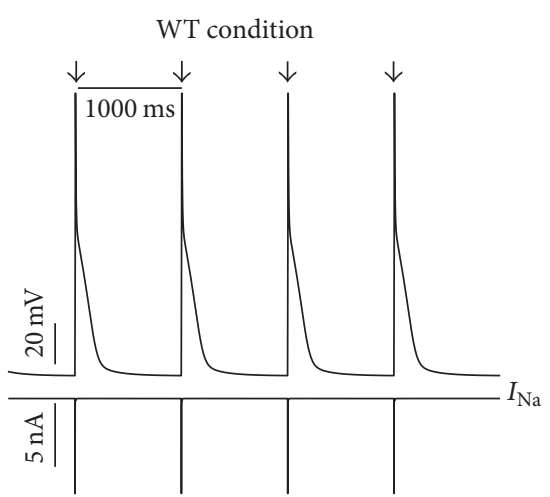

(a)

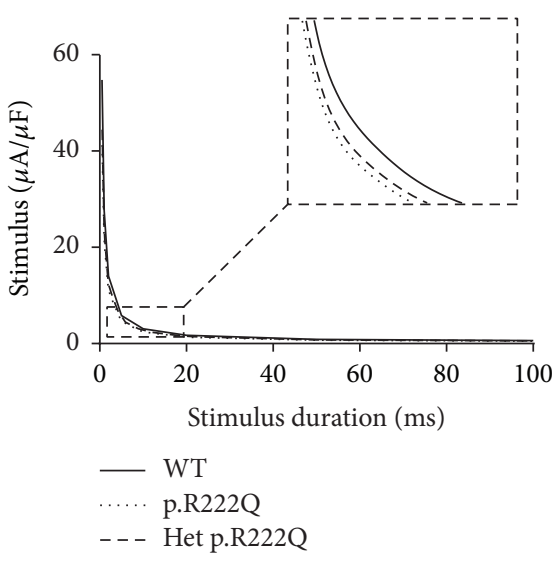

(d)

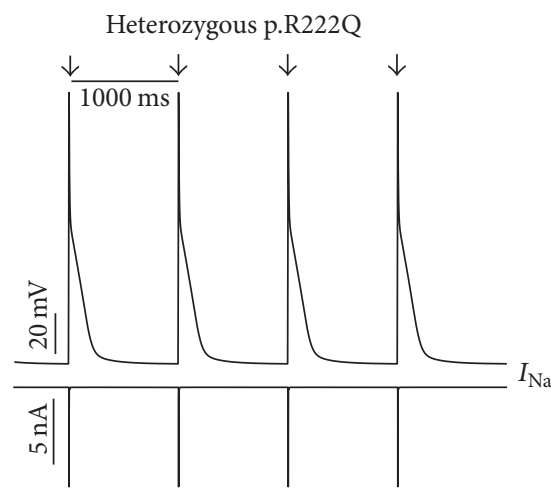

(b)

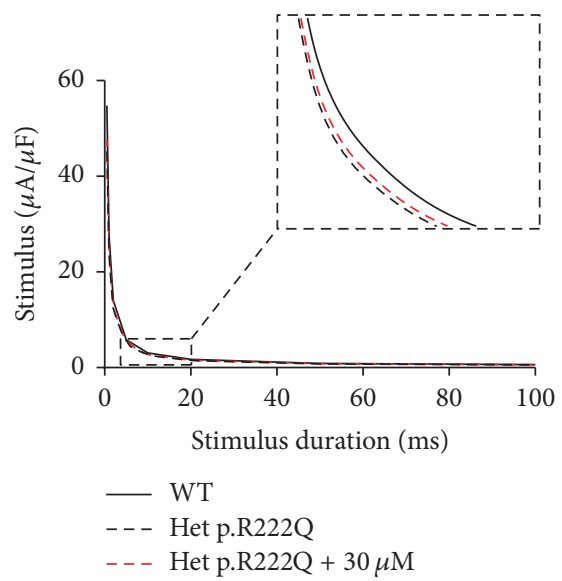

(e)

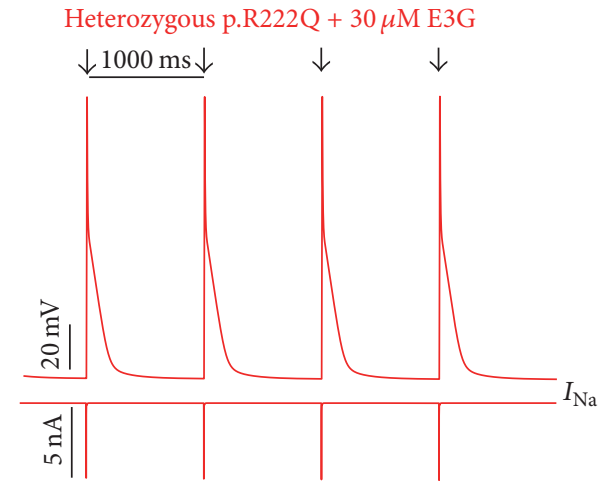

(c)

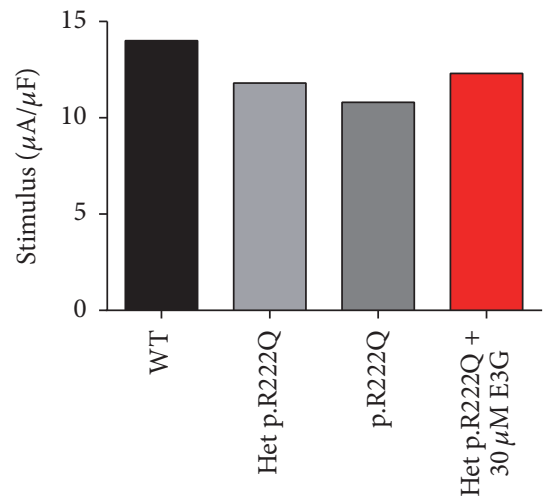

(f)

Figure 8: Effects of $30 \mu \mathrm{M}$ E3G on atrial cell action potentials for $\mathrm{Na}_{\mathrm{v} 1.5}-\mathrm{WT}$ and $\mathrm{Na}_{\mathrm{v1} 1.5}-\mathrm{p} . \mathrm{R} 222 \mathrm{Q}$ conditions (MGTG cell model). (a), (b), and (c) Simulated APs (Top of the panels) and the cardiac sodium currents (Bottom of the panels) in WT, heterozygous $\mathrm{Na}_{\mathrm{v} 1.5}-\mathrm{p} . \mathrm{R} 222 \mathrm{Q}$, and heterozygous $\mathrm{Na}_{\mathrm{v} 1.5}$-p.R222Q $+30 \mu \mathrm{M}$ conditions at $1 \mathrm{~Hz}$ cycle length. Arrows: external stimulus. (d) and (e) Strength-duration curves in the MGTG cell model for $\mathrm{Na}_{\mathrm{v} 1.5}$-WT and heterozygous $\mathrm{Na}_{\mathrm{v} 1.5}$-p.R222Q conditions with or without $30 \mu \mathrm{M}$ E3G (inset, zoom on the strengthduration curves). (f) Excitation thresholds at $2 \mathrm{~ms}$ stimulus duration in the MGTG atrial AP or without $30 \mu \mathrm{M}$ E3G.

Of note, strength-duration curves and conduction velocities could not be established at $1 \mathrm{~Hz}$ in the Purkinje model because of the accelerated spontaneous rhythm caused by p.R222Q and p.I141V mutations.

\subsection{Antiarrhythmic Effect of E3G on SCN5A-Related Cardiac} Syndrome, MEPPC, and EPVT. To investigate the potential antiarrhythmic effect of E3G on $\mathrm{Na}_{\mathrm{v} 1.5}$-p.R222Q and $\mathrm{Na}_{\mathrm{v} 15^{-}}$ p.I141V-related cardiac syndromes, the reported experimental effects of E3G were tested on these mutants. As shown in (a), (b), and (c) in Figures 8-11, 30 $\mu \mathrm{M}$ E3G does not affect the shape of action potentials in atrial and ventricular cells compared to the WT, $\mathrm{Na}_{\mathrm{v} 1.5}$-p.R222Q, and $\mathrm{Na}_{\mathrm{v} 1.5}$-p.I141V heterozygous conditions. However, this compound suppressed the ectopic APs observed in the presence of $\mathrm{Na}_{\mathrm{v} 1.5}-\mathrm{p} . \mathrm{R} 222 \mathrm{Q}$ mutation in Purkinje cell model (Figure 12(c)). Similar effects were obtained for $\mathrm{Na}_{\mathrm{v} 1.5}$-p.I141V mutation. Indeed, E3G decreased the number of ectopic beats associated with the presence of this mutation in Purkinje cells (Figure 13(c)). Of note, for these simulations, the models were stabilized during $60 \mathrm{~s}$, then supplementary run was started for another
$60 \mathrm{~s}$, and finally the last $5 \mathrm{~s}$ of each supplementary run was analyzed.

Moreover, simulations were run using MGTG, TNNP, and SANNBZ cell models, and the strength-duration curves were constructed. In these models, the addition of $30 \mu \mathrm{M}$ E3G decreased the excitability of the atrial, ventricular, and Purkinje cells by increasing the excitation threshold for action potential generation ((e) and (f) in Figures 8-13).

Finally, the effect of E3G on conduction velocity was investigated in the presence of p.R222Q and p.I141V mutations using fibers of atrial, ventricular, and Purkinje cell models. The presence of $30 \mu \mathrm{M}$ E3G attenuates the effect of p.R222Q and p.I141V mutations by decreasing atrial, ventricular, and Purkinje conductions. Of note, the conduction velocity was calculated at $1 \mathrm{~Hz}$ for the atrial and ventricular models and at $2.5 \mathrm{~Hz}$ for the Purkinje cells (Table 4).

\section{Discussion}

The aim of this study was to evaluate the benefits-risks balance of E3G consumption on the setting of cardiac 


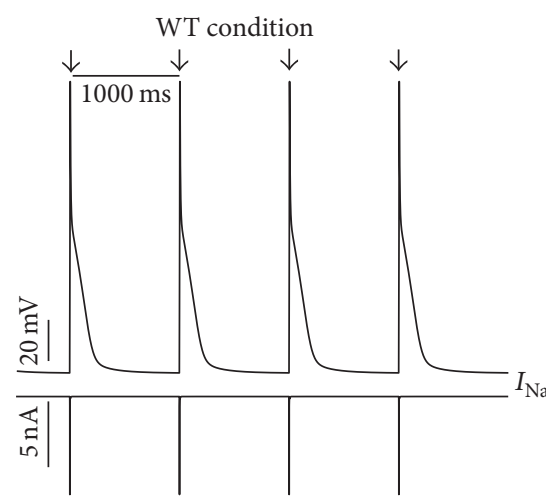

(a)

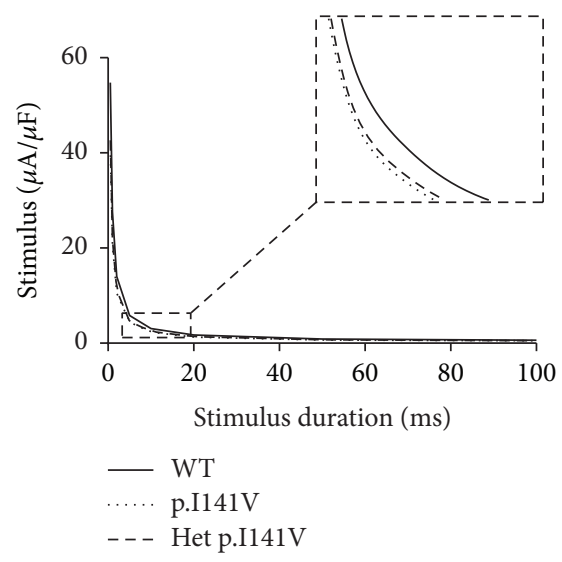

(d)

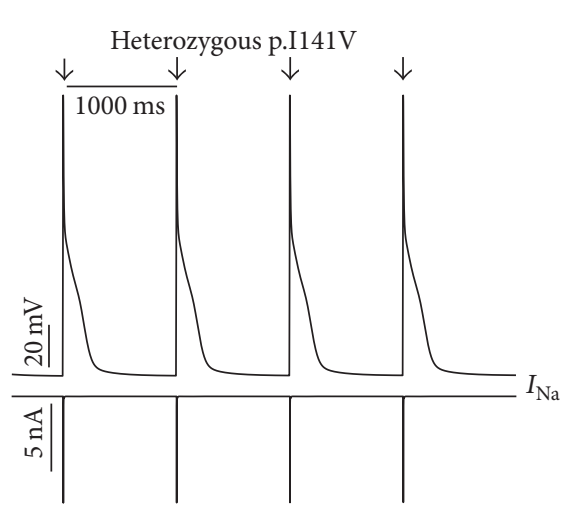

(b)

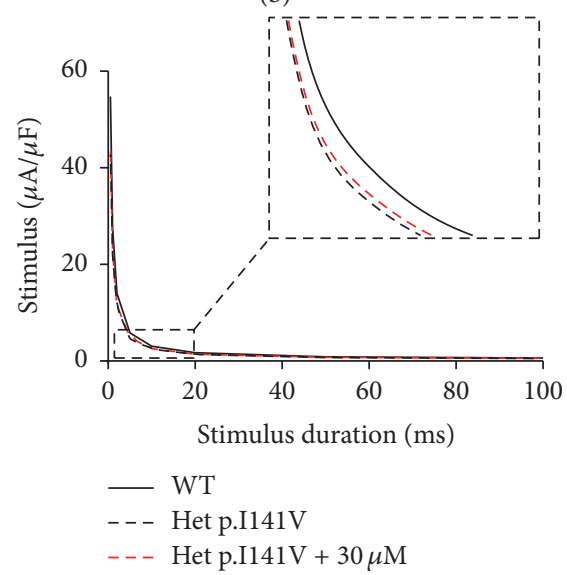

(e)

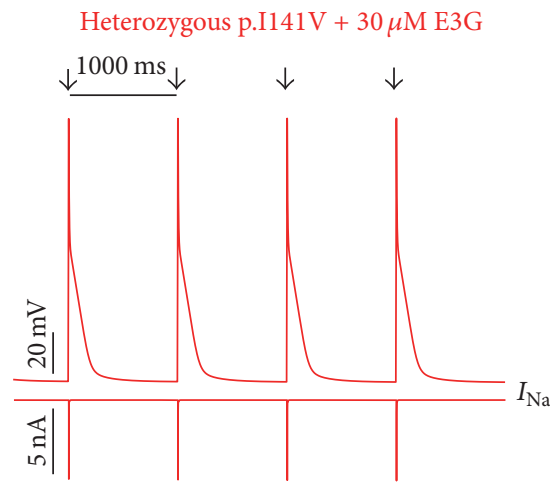

(c)

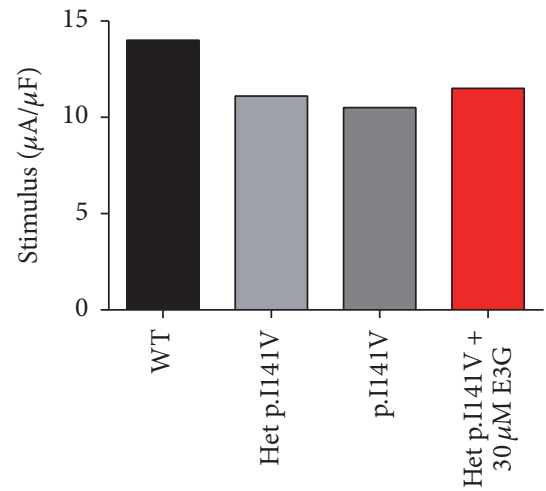

(f)

Figure 9: Effects of $30 \mu \mathrm{M}$ E3G on atrial cell action potentials for $\mathrm{Na}_{\mathrm{v1} .5}-\mathrm{WT}$ and $\mathrm{Na}_{\mathrm{v} 1.5}$-p.I141V conditions (MGTG cell model). (a), (b), and (c) Simulated APs (Top of the panels) and the cardiac sodium currents (Bottom of the panels) in WT, heterozygous Na $\mathrm{v}_{\mathrm{v} .5}-\mathrm{p} . \mathrm{I141V}$, and heterozygous $\mathrm{Na}_{\mathrm{v} 1.5}$-p.I141V $+30 \mu \mathrm{M}$ conditions at $1 \mathrm{~Hz}$ cycle length. Arrows: external stimulus. (d) and (e) Strength-duration curves in the MGTG cell model for $\mathrm{Na}_{\mathrm{v} 1.5}$-WT and heterozygous $\mathrm{Na}_{\mathrm{v} 1.5}$-p.I141V conditions with or without $30 \mu \mathrm{M}$ E3G (inset, zoom on the strengthduration curves). (f) Excitation thresholds at $2 \mathrm{~ms}$ stimulus duration in the MGTG atrial AP or without $30 \mu \mathrm{M}$ E3G.

channelopathies. Two gain-of-function mutations, $\mathrm{Na}_{\mathrm{v} 1.5^{-}}$ p.R222Q and $\mathrm{Na}_{\mathrm{v} 1.5}$-p.I141V, linked, respectively, with MEPPC and EPVT have been studied. Computer simulations of action potentials showed that $30 \mu \mathrm{M}$ E3G reduced the excitability of Purkinje cells for the EPVT and suppressed the AP abnormalities characteristic of the MEPPC phenotype.

\subsection{Simulated Effect of E3G on the Electrophysiological Proper-} ties of Cardiac Cells. Epigallocatechin-3-Gallate is the major catechin found in green tea. Tested at a dose of $30 \mu \mathrm{M}, \mathrm{E} 3 \mathrm{G}$ modulates several voltage gated ion channels such as sodium, L-type calcium, and KCNQ1 channels [8]. Thus, the perfusion of this catechin induces several electrocardiographic modifications in Langendorff-perfused guinea pig hearts [8]. Indeed, E3G prolonged PR and QRS intervals, slightly shortened the QT interval, and altered the shape of the ST-Twave segment [8]. To explain the link between these effects, in silico E3G effects were reproduced as described by Kang et al. [8]. Then, the effect of these modifications was evaluated on cardiac action potentials. Either for atrial, ventricular, or Purkinje cell models, our simulations showed delayed action potentials upstrokes, decreased APs amplitudes, and reduced conduction velocity in these cell models. These effects are likely related to the inhibition of the cardiac sodium channel by E3G. In fact, these parameters result mainly from the passage of sodium ions through these channels. Therefore, E3G effects are reflected on the whole heart activity by the prolongation of the PR and QRS intervals.

On the other hand, the experimental work of Kang et al. showed a slight decrease of the QT interval when E3G is perfused [8]. These findings are consistent with our results showing a slight diminution of ventricular AP duration in presence of E3G. However, our simulations failed to explain the increase of the interval from the peak of the $\mathrm{T}$ wave to the end of the $T$ wave $\left(T_{p}-T_{e}\right)$ on the resting guinea pig ECG. This interval reflects the transmural dispersion of repolarization in the ventricle $[20,21]$. Accordingly, it was shown that the increase of this interval could be associated with an increase of the repolarization heterogeneity across the ventricular wall with an increased risk of sudden cardiac death [22]. In contrast to these evidences, our results predicted a slight decrease of this heterogeneity. 


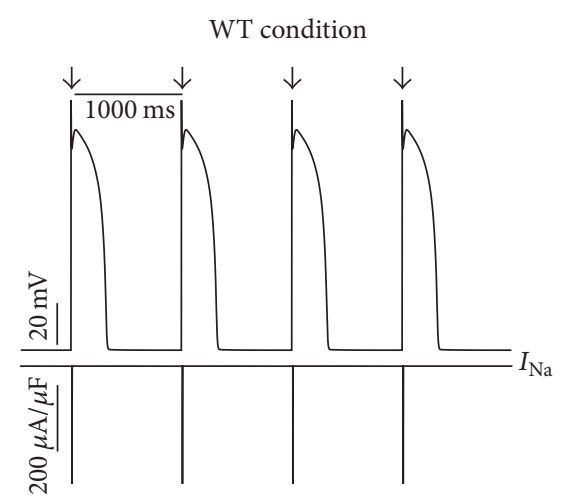

(a)

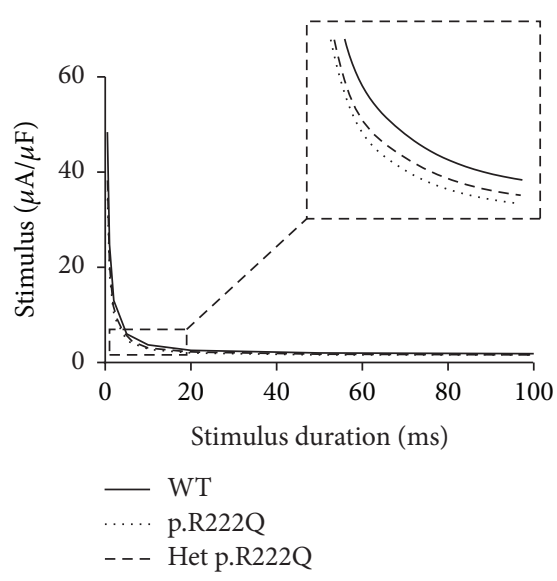

(d)

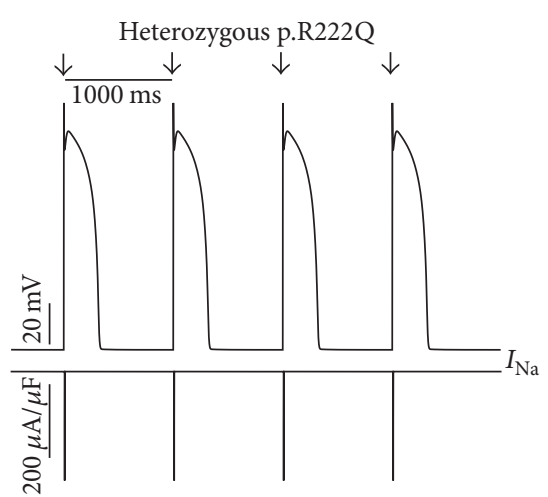

(b)

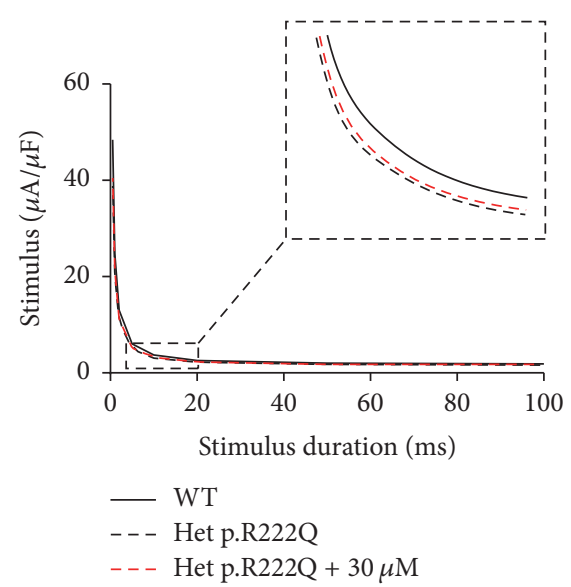

(e)

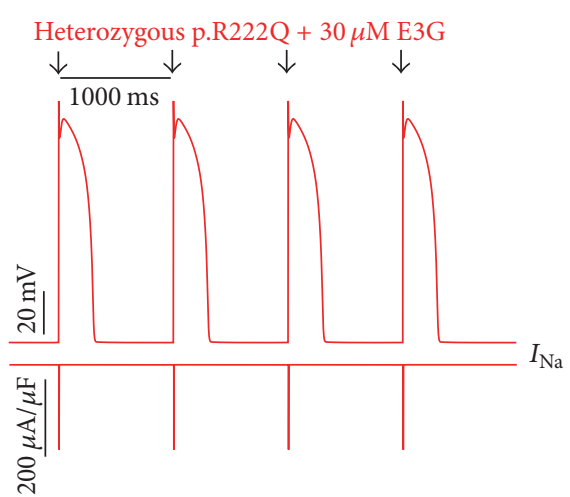

(c)

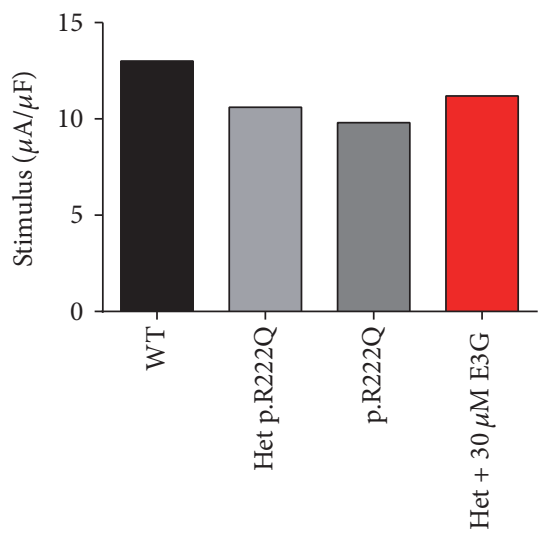

(f)

FIGURE 10: Effects of $30 \mu \mathrm{M}$ E3G on ventricular cell action potentials for $\mathrm{Na}_{\mathrm{v} 1.5}-\mathrm{WT}$ and $\mathrm{Na}_{\mathrm{v} 1.5}-\mathrm{p} \cdot \mathrm{R} 222 \mathrm{Q}$ conditions (TNNP cell model). (a), (b), and (c) Simulated APs (Top of the panels) and the cardiac sodium currents (Bottom of the panels) in WT, heterozygous Na $\mathrm{v}_{1.5}-\mathrm{p} . \mathrm{R} 222 \mathrm{Q}$, and heterozygous $\mathrm{Na}_{\mathrm{v} 1.5}-\mathrm{p} . \mathrm{R} 222 \mathrm{Q}+30 \mu \mathrm{M}$ conditions at $1 \mathrm{~Hz}$ cycle length. Arrows: external stimulus. (d) and (e) Strength-duration curves in the TNNP cell model for $\mathrm{Na}_{\mathrm{v} 1.5}-\mathrm{WT}$ and heterozygous $\mathrm{Na}_{\mathrm{v} 1.5}-\mathrm{p} . \mathrm{R} 222 \mathrm{Q}$ conditions with or without $30 \mu \mathrm{M} \mathrm{E} 3 \mathrm{G}$ (inset, zoom on the strengthduration curves). (f) Excitation thresholds at $2 \mathrm{~ms}$ stimulus duration in the TNNP atrial AP or without $30 \mu \mathrm{M}$ E3G.

4.2. The p.R222Q and p.II41V Effects on Cardiac Excitability. In order to evaluate the possible antiarrhythmic effect of E3G in the sitting of MEPPC and EPVT cardiac disorders, the biophysical modifications induced by the $\mathrm{Na}_{\mathrm{v} 1.5}$-p.R222Q and $\mathrm{Na}_{\mathrm{v} 1.5}-\mathrm{p} . \mathrm{I} 141 \mathrm{~V}$ mutants were incorporated as previously described by Mann et al. and Swan et al. [3, 4]. As shown by these groups, the introduction of these modifications into the atrial and ventricular cell models does not affect their AP morphologies. In contrast, the incorporation of the $\mathrm{Na}_{\mathrm{v} 1.5}$-p.R222Q and $\mathrm{Na}_{\mathrm{v} 1.5}$-p.I141V biophysical effects in the Purkinje cell model strongly affects the normal activation of these cells. Indeed, for these mutants, the model showed an accelerated rate of spontaneous activity of Purkinje cells leading to the occurrence of ectopic beats during the diastolic interval. In relevance to the disappearance of clinically observed premature contractions during exercise, the Purkinje ectopic APs induced by $\mathrm{Na}_{\mathrm{v} 1.5}$-p.R222Q mutation disappear at high pacing rates (Data not shown).

On the other hand, in atrial, ventricular, and Purkinje models, the presence of $\mathrm{Na}_{\mathrm{v} 1.5}$-p.R222Q and $\mathrm{Na}_{\mathrm{v} 1.5^{-}}$ p.I141V mutations lowers the excitation thresholds for action potential generation compared with the WT. Thus, threshold potential could be rapidly reached during the diastolic depolarization phase and consequently fire more action potentials in the Purkinje fiber compared to the WT condition. In contrast, atrial and ventricular cells do not show any spontaneous or ectopic activity in the presence of $\mathrm{Na}_{\mathrm{v} 1.5}-\mathrm{p} . \mathrm{R} 222 \mathrm{Q}$ and $\mathrm{Na}_{\mathrm{v} 1.5}-$ p.I141V mutations. The biophysical modification induced by these mutations may promote the onset of arrhythmias by increasing the excitability of atrial and ventricular cells but cannot induce a spontaneous activation of these cells. Thus, as described by Laurent et al., the premature ventricular contraction observed in the affected patients may be triggered via the abnormal activity of the Purkinje fibers in the presence of p.R222Q and p.I141V mutations [2].

Moreover, the investigation of conduction velocity in fibers of MGTG, TNNP, and SANNBZ cell models shows an accelerated atrial, ventricular, and Purkinje conduction in the presence of $\mathrm{Na}_{\mathrm{v} 1.5}$-p.I141V mutation. Similar variations were observed in $\mathrm{Na}_{\mathrm{v} 1.5}$-p.R222Q mutation, whereas the conduction velocity was lower than WT condition in Purkinje cell model. The difference between the two mutations is related to 


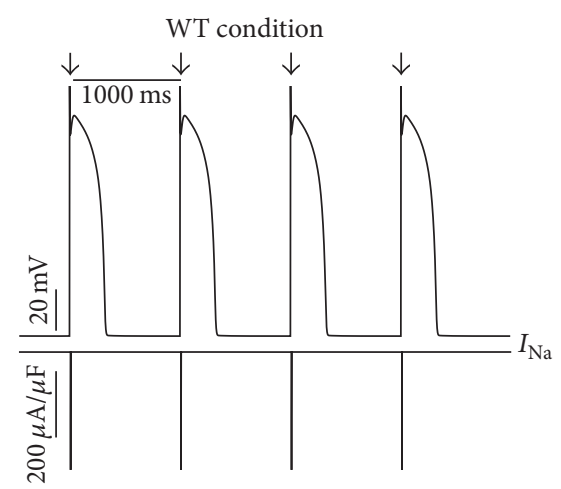

(a)

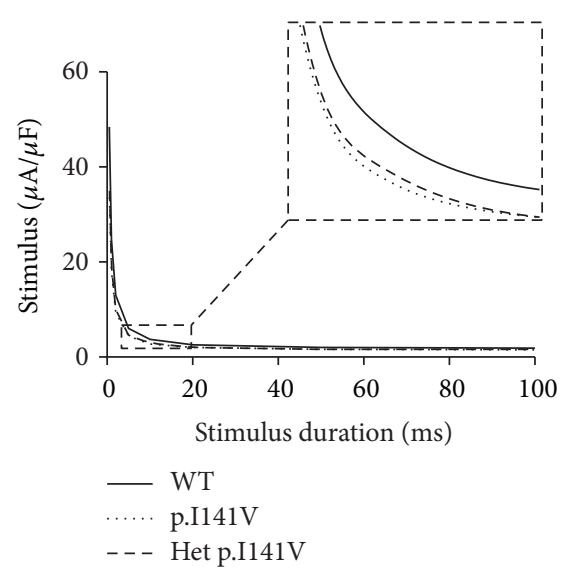

(d)

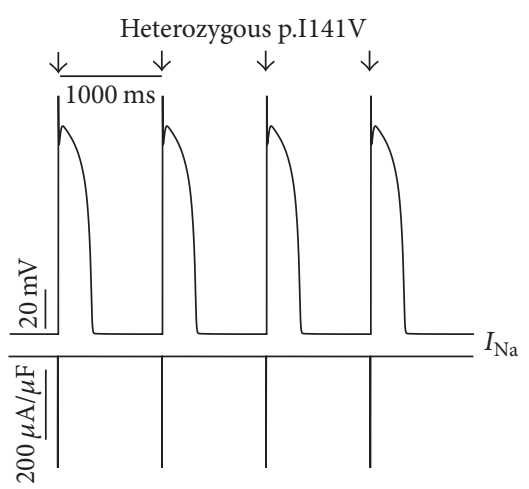

(b)

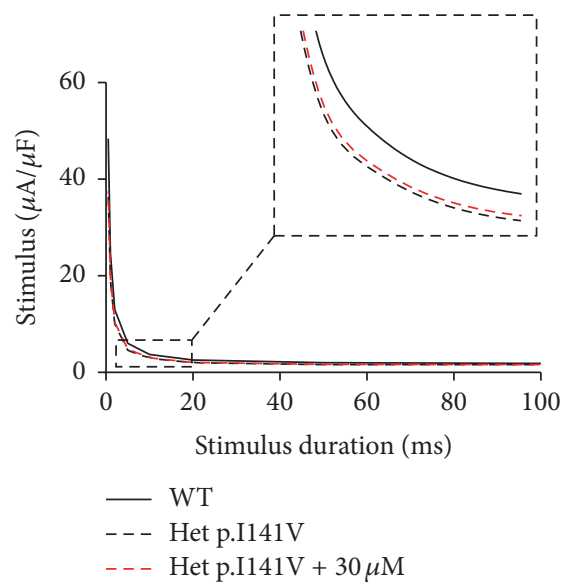

(e)

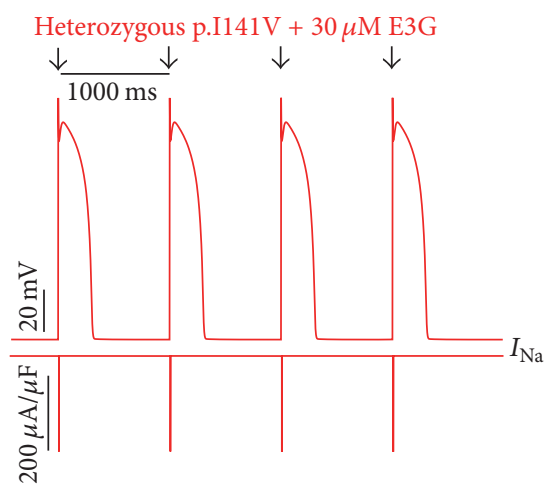

(c)

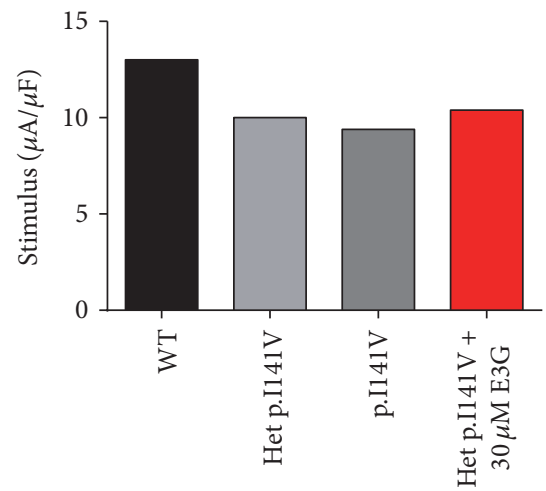

(f)

FIGURE 11: Effects of $30 \mu \mathrm{M}$ E3G on ventricular cell action potentials for $\mathrm{Na}_{\mathrm{v} 1.5}-\mathrm{WT}$ and $\mathrm{Na}_{\mathrm{v} 1.5}-$ p.I141V conditions (TNNP cell model). (a), (b), and (c) Simulated APs (Top of the panels) and the cardiac sodium currents (Bottom of the panels) in WT, heterozygous Na $\mathrm{v}_{\mathrm{v} .5}-\mathrm{p}$.I141V, and heterozygous $\mathrm{Na}_{\mathrm{v} 1.5}$-p.I141V $+30 \mu \mathrm{M}$ conditions at $1 \mathrm{~Hz}$ cycle length. Arrows: external stimulus. (d) and (e) Strength-duration curves in the TNNP cell model for $\mathrm{Na}_{\mathrm{v} 1.5}-\mathrm{WT}$ and heterozygous $\mathrm{Na}_{\mathrm{v} 1.5}-$ p.I141V conditions with or without $30 \mu \mathrm{M}$ E3G (inset, zoom on the strengthduration curves). (f) Excitation thresholds at $2 \mathrm{~ms}$ stimulus duration in the TNNP atrial AP or without $30 \mu \mathrm{M}$ E3G.

the left shift of the steady state of inactivation shown by the $\mathrm{Na}_{\mathrm{v} 1.5}$-p.R222Q mutant. Indeed, when the $\mathrm{Na}_{\mathrm{v} 1.5}$-p.R222Q effect on the steady state of inactivation was suppressed, an increase of the conduction velocity was observed (Data not shown).

\subsection{Antiarrhythmic Effect of E3G on the MEPPC and EPVT} Syndromes. By implementing the experimental functional effects of E3G on the cardiac ion channels, we investigated whether E3G had an antiarrhythmic effect on $\mathrm{Na}_{\mathrm{v} 1.5}$-p.R222Q and $\mathrm{Na}_{\mathrm{v} 1.5}$-p.I141V-related cardiac syndromes.

Regarding the $\mathrm{Na}_{\mathrm{v} 1.5}-\mathrm{p} . \mathrm{R} 222 \mathrm{Q}$ mutation, the application of $30 \mu \mathrm{M} \mathrm{E} 3 \mathrm{G}$ suppressed the ectopic APs characteristic of the MEPPC phenotype. However, at the same dose, E3G partially reduced the frequency of ectopic beats observed in Purkinje cells for the EPVT. These effects could be related to the inhibitory action of this compound on cardiac sodium channels, as was described in some antiarrhythmic drugs such as
Quinidine and flecainide $[2,23]$. In addition, the increase of excitation threshold for action potential generation and the decrease of conduction velocities, in the presence of $30 \mu \mathrm{M}$ E3G, may also limit the cardiac cells hyperexcitability that is related to gain of functions mutations of the cardiac sodium channels.

On the other hand, a clear difference in E3G effect was observed between the MEPPC and EPVT disorders. This difference could be explained by the biophysical properties of $\mathrm{Na}_{\mathrm{v} 1.5}$-p.R222Q and $\mathrm{Na}_{\mathrm{v} 1.5}$-p.I141V mutants. Indeed, in contrast to the $\mathrm{Na}_{\mathrm{v} 1.5}$-p.I141V mutation, known by the sole modification of the activation process of $\mathrm{Na}_{\mathrm{v} 1.5}$, the $\mathrm{Na}_{\mathrm{v} 1.5^{-}}$ p.R222Q mutation shifted the activation and inactivation processes towards more negative potentials $[2,3]$. Therefore, E3G generated a more pronounced loss of function in the $\mathrm{Na}_{\mathrm{v} 1.5}$-p.R222Q mutant than the $\mathrm{Na}_{\mathrm{v} 1.5}$-p.I141V one. This is presumably due to the magnification of the negative shifts of $\mathrm{Na}_{\mathrm{v} 1.5}$ steady state inactivation induced in presence of both E3G and $\mathrm{Na}_{\mathrm{v} 1.5}$-p.R222Q. 


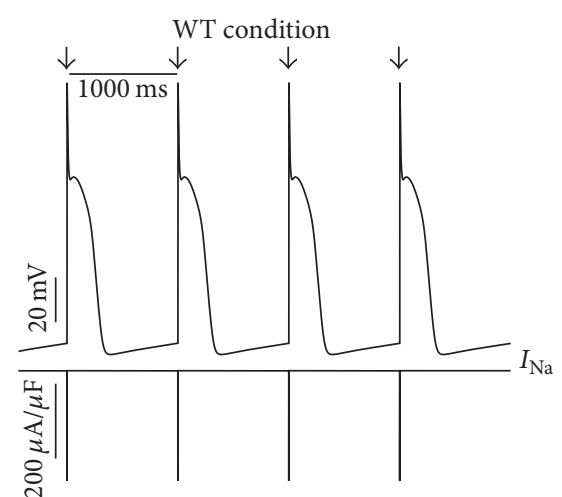

(a)

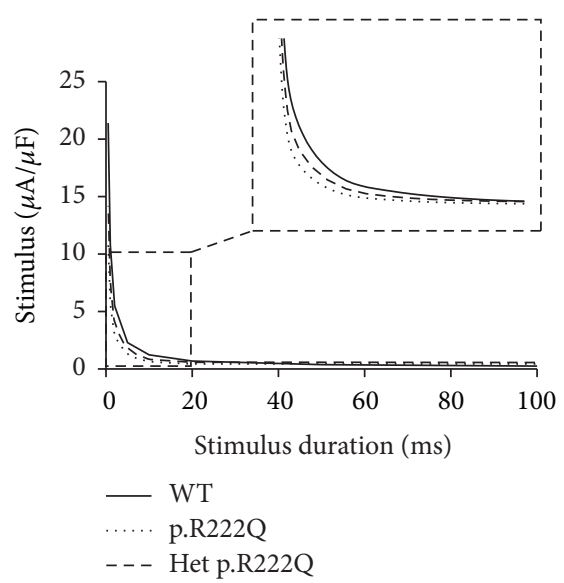

(d)

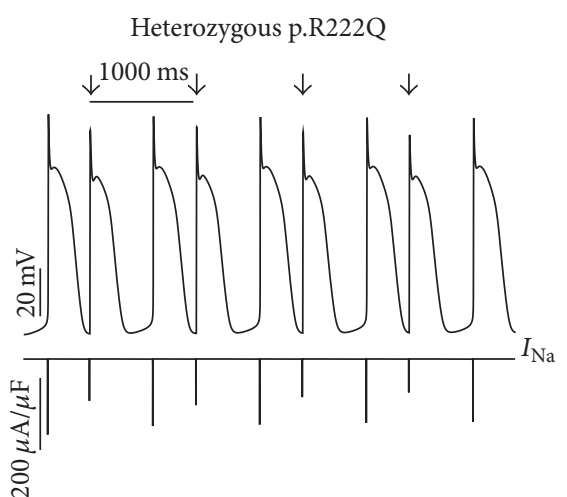

(b)

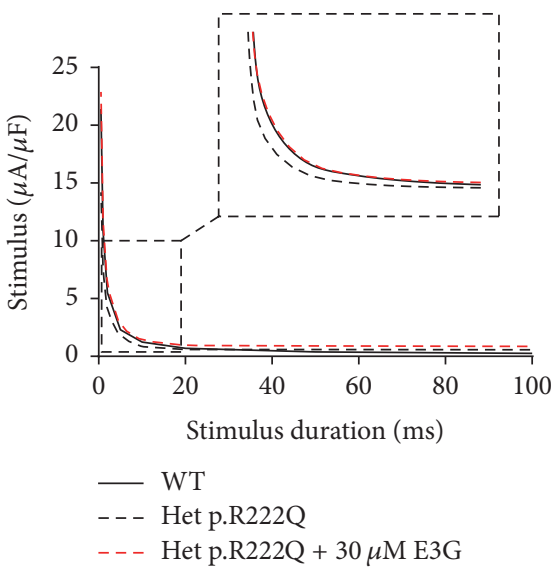

(e)

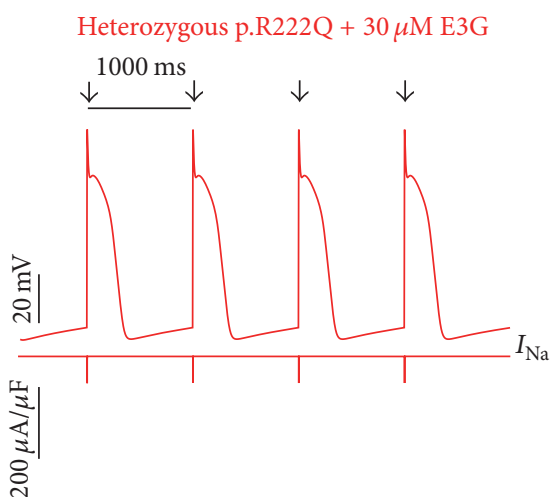

(c)

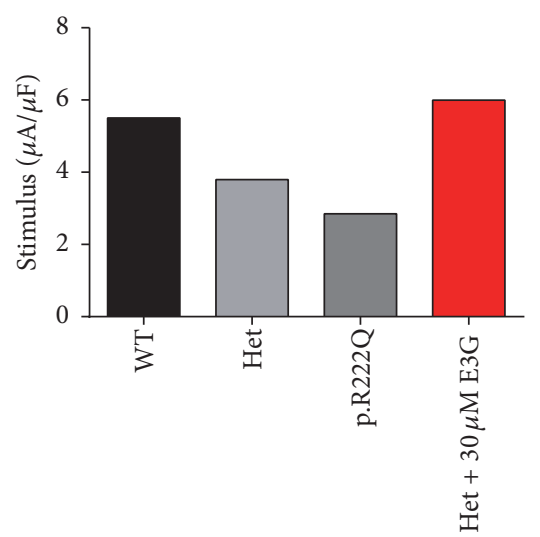

(f)

Figure 12: Effects of $30 \mu \mathrm{M}$ E3G on Purkinje cell action potentials for $\mathrm{Na}_{\mathrm{v} 1.5}-\mathrm{WT}$ and $\mathrm{Na}_{\mathrm{v} 1.5}$-p.R222Q conditions (SANNBZ cell model). (a), (b), and (c) Simulated APs (Top of the panels) and the cardiac sodium currents (Bottom of the panels) in WT, heterozygous Na $\mathrm{v}_{\mathrm{v} .5}{ }^{-}$p.R222 Q, and heterozygous $\mathrm{Na}_{\mathrm{v} 1.5}$-p.R222Q $+30 \mu \mathrm{M}$ conditions at $1 \mathrm{~Hz}$ cycle length. Arrows: external stimulus. (d) and (e) Strength-duration curves in the SANNBZ cell model for $\mathrm{Na}_{\mathrm{v} 1.5}$-WT and heterozygous $\mathrm{Na}_{\mathrm{v} 1.5}$-p.R222Q conditions with or without $30 \mu \mathrm{M} \mathrm{E} 3 \mathrm{G}$ at $2.5 \mathrm{~Hz}$ (inset, zoom on the strength-duration curves). (f) Excitation thresholds at $2 \mathrm{~ms}$ stimulus duration in the SANNBZ atrial AP or without $30 \mu \mathrm{M}$ E3G.

\section{Conclusion}

The present simulations suggest that E3G consumption may have a beneficial effect in the setting of cardiac sodium channelopathies displaying hyperexcitability phenotypes. Thus, this compound may offer a new promising alternative to prevent and treat the episodes of arrhythmia.

\section{Additional Points}

Limitations of the Study. The current study has several limitations: (i) the used cellular models did not incorporate the effects of adrenergic stimulation. (ii) Any biological variability was incorporated in these simulations. (iii) We assumed that WT and mutants ions channels have similar affinity to E3G. (iv) Kinetic effects of E3G were not considered in this study. (v) Cell-level arrhythmias such as early after depolarization and delayed after depolarization, or reentry, are not investigated in the current study. (vi) Any comparison of E3G effects was realized in the used action potential models.

\section{Competing Interests}

The authors declare that they have no competing interests.

\section{Authors' Contributions}

Professors Mohamed-Yassine Amarouch and Driss Mazouzi contributed equally to this work as senior authors.

\section{Acknowledgments}

The authors would like to thank (i) Professor Jan P. Kucera, Department of Physiology, University of Bern, Switzerland, for his comments on this manuscript and (ii) Michael Clerx, Maastricht University, Netherlands, for his technical help with Myokit software. 


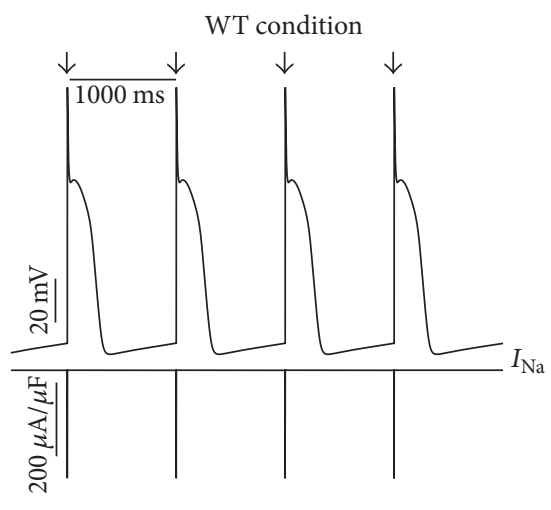

(a)

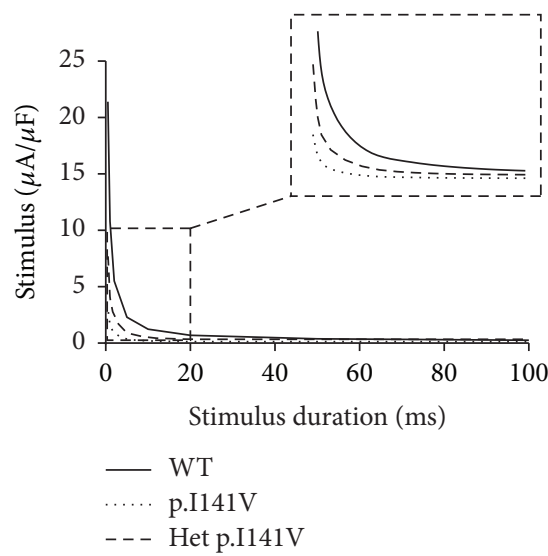

(d)

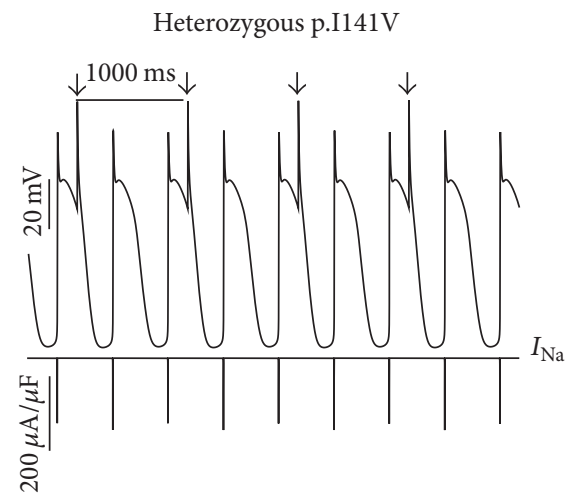

(b)

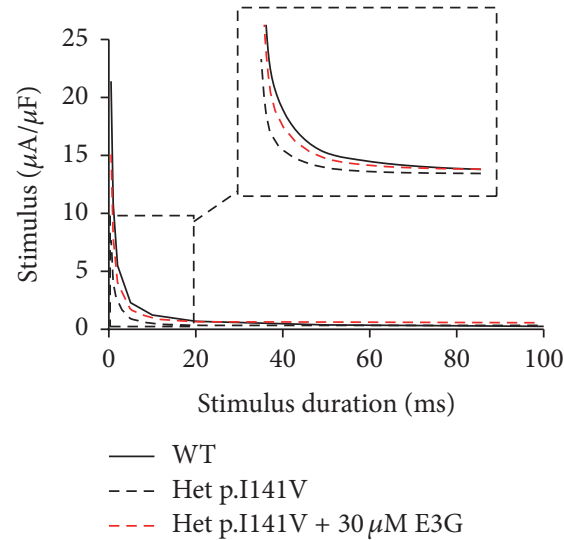

(e)

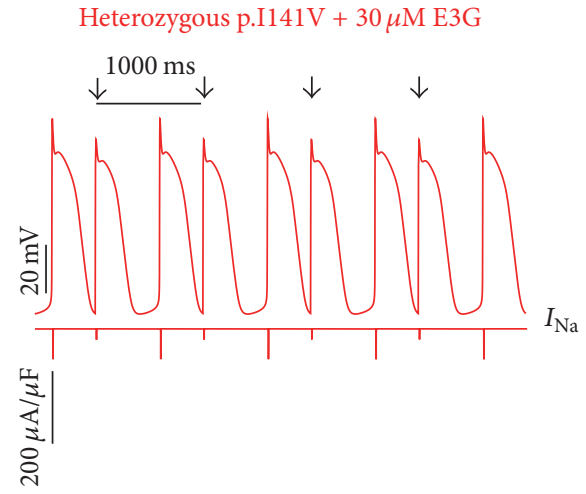

(c)

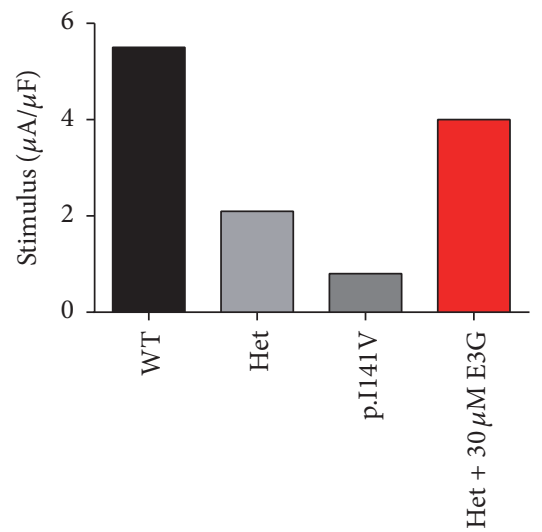

(f)

Figure 13: Effects of $30 \mu \mathrm{M}$ E3G on Purkinje cell action potentials for $\mathrm{Na}_{\mathrm{v} 1.5}-\mathrm{WT}$ and $\mathrm{Na}_{\mathrm{v} 1.5}$-p.I141V conditions (SANNBZ cell model). (a), (b), and (c) Simulated APs (Top of the panels) and the cardiac sodium currents (Bottom of the panels) in WT, heterozygous Na $\mathrm{v}_{\mathrm{v} .5}-\mathrm{p} . \mathrm{I1} 1 \mathrm{lV}$, and heterozygous $\mathrm{Na}_{\mathrm{v} 1.5}$-p.I141V $+30 \mu \mathrm{M}$ conditions at $1 \mathrm{~Hz}$ cycle length. Arrows: external stimulus. (d) and (e) Strength-duration curves in the SANNBZ cell model for $\mathrm{Na}_{\mathrm{v} 1.5}$-WT and heterozygous $\mathrm{Na}_{\mathrm{v} 1.5}$-p.I141V conditions with or without $30 \mu \mathrm{M} \mathrm{E} 3 \mathrm{G}$ at $2.5 \mathrm{~Hz}$ (inset, zoom on the strength-duration curves). (f) Excitation thresholds at $2 \mathrm{~ms}$ stimulus duration in the SANNBZ atrial AP or without $30 \mu \mathrm{M}$ E3G.

\section{References}

[1] H. Abriel and E. V.Zaklyazminskaya, "Cardiac channelopathies: genetic and molecular mechanisms," Gene, vol. 517, no. 1, pp. 111, 2013.

[2] G. Laurent, S. Saal, M. Y. Amarouch et al., "Multifocal ectopic Purkinje-related premature contractions: a new SCN5A-related cardiac channelopathy," Journal of the American College of Cardiology, vol. 60, no. 2, pp. 144-156, 2012.

[3] S. A. Mann, M. L. Castro, M. Ohanian et al., "R222Q SCN5A mutation is associated with reversible ventricular ectopy and dilated cardiomyopathy," Journal of the American College of Cardiology, vol. 60, no. 16, pp. 1566-1573, 2012.

[4] H. Swan, M. Y. Amarouch, J. Leinonen et al., "Gain-of-function mutation of the SCN5A gene causes exercise-induced polymorphic ventricular arrhythmias," Circulation: Cardiovascular Genetics, vol. 7, no. 6, pp. 771-781, 2014.

[5] M.-Y. Amarouch, M. A. Kasimova, M. Tarek, and H. Abriel, "Functional interaction between S1 and S4 segments in voltagegated sodium channels revealed by human channelopathies," Channels, vol. 8, no. 5, pp. 414-420, 2014.
[6] M.-Y. Amarouch and H. Abriel, "Cellular hyper-excitability caused by mutations that alter the activation process of voltagegated sodium channels," Frontiers in Physiology, vol. 6, article 45, 2015.

[7] H. A. Fozzard, M. F. Sheets, and D. A. Hanck, "The sodium channel as a target for local anesthetic drugs," Frontiers in Pharmacology, vol. 2, article 68, 2011.

[8] J. Kang, H. Cheng, J. Ji, J. Incardona, and D. Rampe, "In vitro electrocardiographic and cardiac ion channel effects of (-)epigallocatechin-3-gallate, the main catechin of green tea," The Journal of Pharmacology and Experimental Therapeutics, vol. 334, no. 2, pp. 619-626, 2010.

[9] P. V. A. Babu and D. Liu, "Green tea catechins and cardiovascular health: an update," Current Medicinal Chemistry, vol. 15, no. 18, pp. 1840-1850, 2008.

[10] H. N. Graham, "Green tea composition, consumption, and polyphenol chemistry," Preventive Medicine, vol. 21, no. 3, pp. 334-350, 1992.

[11] F. Shahidi, "Antioxidants in food and food antioxidants," Die Nahrung, vol. 44, no. 3, pp. 158-163, 2000.

[12] E. P. Scholz, E. Zitron, H. A. Katus, and C. A. Karle, "Cardiovascular ion channels as a molecular target of flavonoids," Cardiovascular Therapeutics, vol. 28, no. 4, pp. e46-e52, 2010. 
[13] K. Kelemen, C. Kiesecker, E. Zitron et al., "Green tea flavonoid epigallocatechin-3-gallate (EGCG) inhibits cardiac hERG potassium channels," Biochemical and Biophysical Research Communications, vol. 364, no. 3, pp. 429-435, 2007.

[14] M. M. Maleckar, J. L. Greenstein, N. A. Trayanova, and W. R. Giles, "Mathematical simulations of ligand-gated and cell-type specific effects on the action potential of human atrium," Progress in Biophysics and Molecular Biology, vol. 98, no. 2-3, pp. 161-170, 2008.

[15] P. Stewart, O. V. Aslanidi, D. Noble, P. J. Noble, M. R. Boyett, and $\mathrm{H}$. Zhang, "Mathematical models of the electrical action potential of Purkinje fibre cells," Philosophical Transactions of the Royal Society A: Mathematical, Physical and Engineering Sciences, vol. 367, no. 1896, pp. 2225-2255, 2009.

[16] K. H. W. J. Ten Tusscher, D. Noble, P. J. Noble, and A. V. Panfilov, "A model for human ventricular tissue," American Journal of Physiology-Heart and Circulatory Physiology, vol. 286, no. 4, pp. H1573-H1589, 2004.

[17] M. Courtemanche, R. J. Ramirez, and S. Nattel, "Ionic mechanisms underlying human atrial action potential properties: insights from a mathematical model," The American Journal of Physiology-Heart and Circulatory Physiology, vol. 275, no. 1, pp. H301-H321, 1998.

[18] D. DiFrancesco and D. Noble, "A model of cardiac electrical activity incorporating ionic pumps and concentration changes," Philosophical Transactions of the Royal Society of London. Series B: Biological Sciences, vol. 307, no. 1133, pp. 353-398, 1985.

[19] M. Clerx, P. Collins, E. de Lange, and P. G. A. Volders, "Myokit: a simple interface to cardiac cellular electrophysiology," Progress in Biophysics and Molecular Biology, vol. 120, no. 1-3, pp. 100114, 2016.

[20] T. Opthof, R. Coronel, and M. J. Janse, "Is there a significant transmural gradient in repolarization time in the intact heart?: Repolarization gradients in the intact heart," Circulation: Arrhythmia and Electrophysiology, vol. 2, no. 1, pp. 89-96, 2009.

[21] P. Taggart, P. M. I. Sutton, T. Opthof et al., "Transmural repolarisation in the left ventricle in humans during normoxia and ischaemia," Cardiovascular Research, vol. 50, no. 3, pp. 454462, 2001.

[22] R. Panikkath, K. Reinier, A. Uy-Evanado et al., "Prolonged tpeak-to-tend interval on the resting ECG is associated with increased risk of sudden cardiac death," Circulation: Arrhythmia and Electrophysiology, vol. 4, no. 4, pp. 441-447, 2011.

[23] M. Y. Amarouch, H. Swan, J. Leinonen et al., "Antiarrhythmic action of flecainide in polymorphic ventricular arrhythmias caused by a gain-of-function mutation in the Nav1.5 sodium channel," Annals of Noninvasive Electrocardiology, vol. 21, no. 4, pp. 343-351, 2016. 


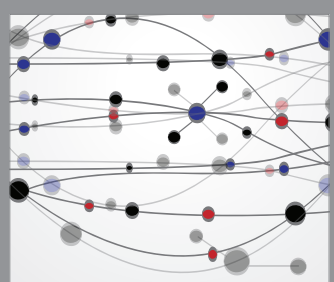

The Scientific World Journal
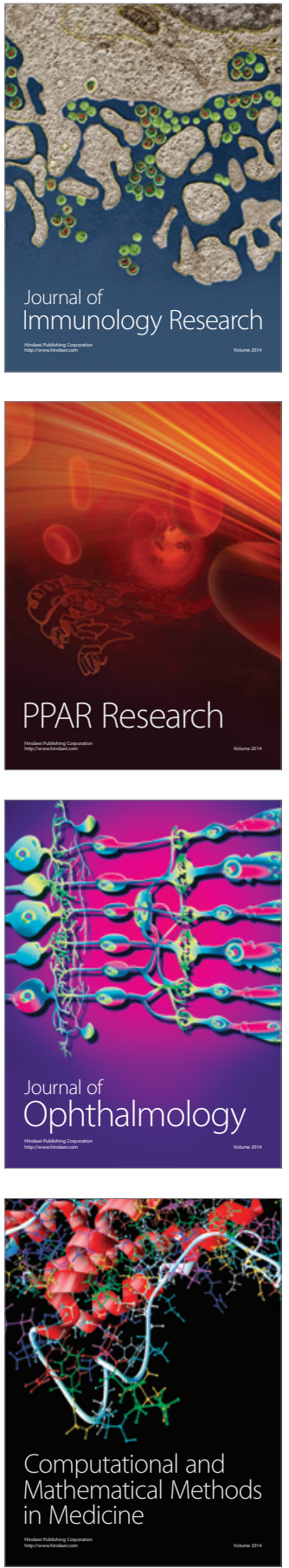

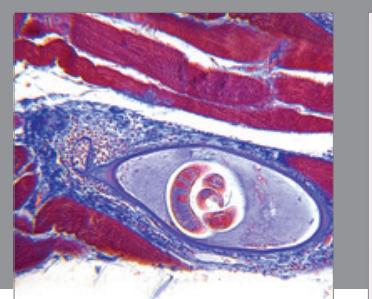

Gastroenterology Research and Practice

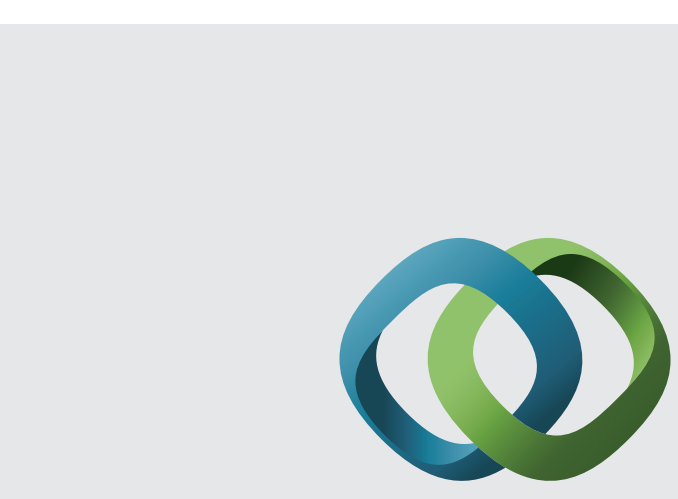

\section{Hindawi}

Submit your manuscripts at

http://www.hindawi.com
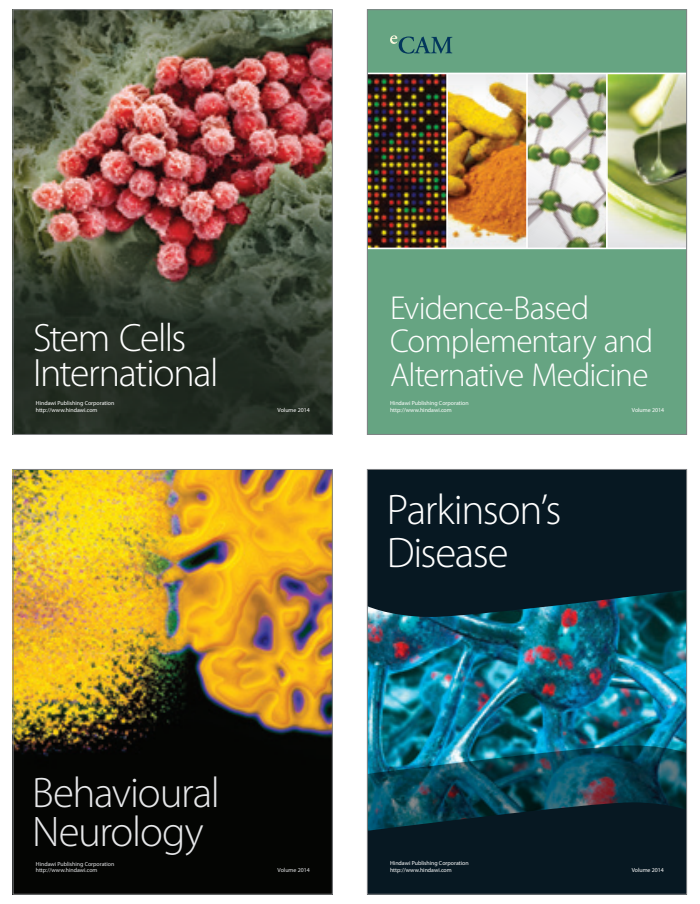
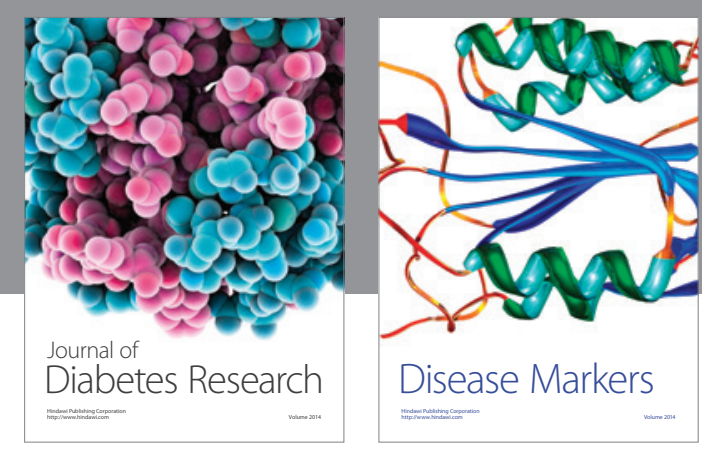

Disease Markers
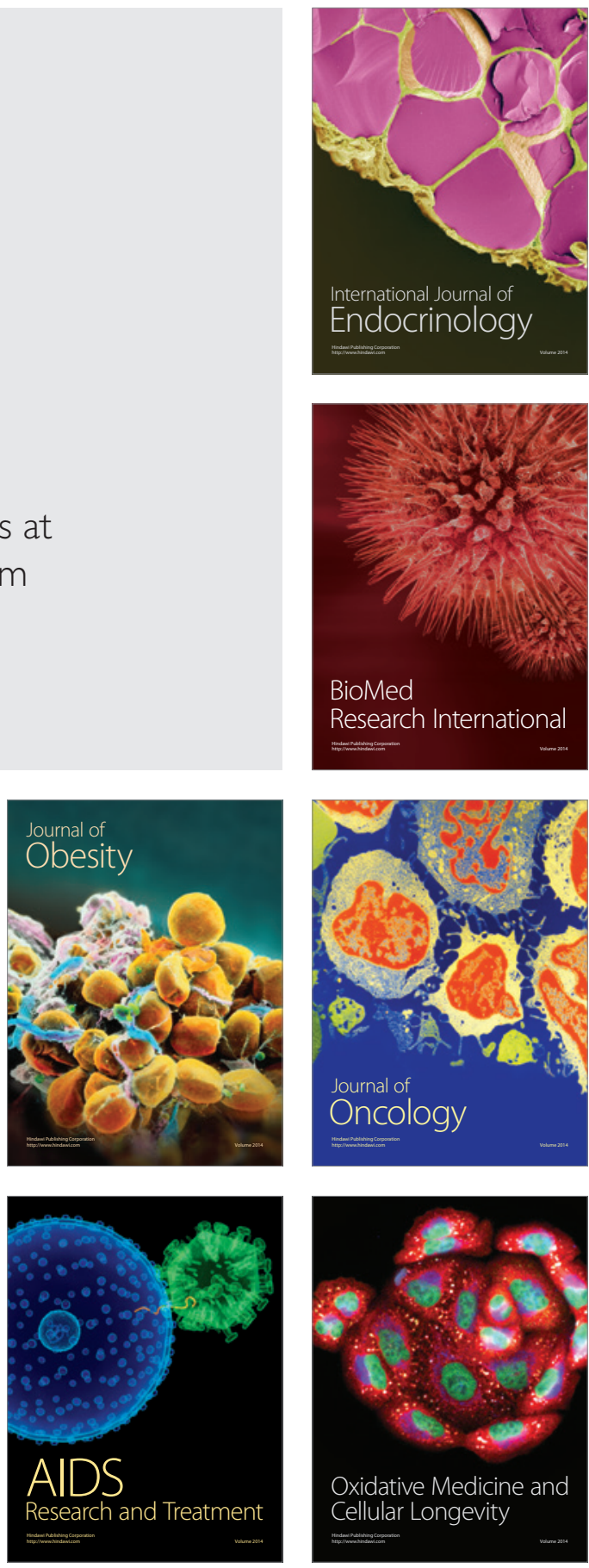